\title{
Fem læsninger af Franz Kafkas »Foran loven«
}

»Foran loven« (»Vor dem Gesetz«) ${ }^{1}$ var én af de tekster, som fandt nåde for den jødisk-tjekkiske forfatter Franz Kafkas selvkritiske øjne som egnet til offentliggørelse i hans levetid. Den udkom som en del af novellesamlingen Ein Landarzt (1919), men havde tidligere været trykt i det jødiske ugemagasin Selbstwehr (1915).

Senere foranstaltede vennen Max Brod en posthum udgivelse af de samlede efterladte skrifter (1935) i direkte modstrid med Kafkas erklærede forlangende om en afbrænding af de ikke-udgivne tekster efter sin død. Brods tilsidesættelse af ophavsmandens intention om tilintetgørelsen af sine værker muliggjorde, at romanen Processen kunne udgives og i dag betragtes som en moderne klassiker.

Hele fortællingen »Foran loven« citeres ordret i Processen, hvor den fremføres som et lærestykke af en præst i samtale med protagonisten Josef K. Denne placering af novellen i Kafkas mest prominente værk har i det meste af eftertidens forskning berøvet »Foran loven« dens oprindelige selvstændighed.

I henhold til Kafkas egen valorisering af de to tekster - forudsat at offentliggørelse implicerer en værdidom - forekommer det at være en besynderligt ensidig fremgangsmåde. Udgivelsen af »Foran loven« indikerer, at Kafka opfattede den som en i sig selv afrundet tekst. Og tilbageholdelsen af Processen fra udgivelse indikerer, at dette værk enten simpelthen aldrig nåede at blive færdigt, eller at det aldrig nåede at få en udformning, som kunne tilfredsstille forfatterens kunstneriske ambitionsniveau.

Dette spor og denne forfatterintention vil denne artikel forfølge ved at omvende den traditionelle litterære kritiks fokuseringsmåde og lade »Foran loven« være det primære analyseobjekt, mens Processen vil spille en underordnet rolle som den (ramme-)fortælling, der kan give fingerpeg om én af de flere mulige fortolkninger af novellen.

Enhver fortolkning af »Foran loven« vil afhænge af, hvad læseren måtte forudsætte, at loven repræsenterer. Blot kan det ikke afgøres, hvilken lov der er tale om, da den ikke gives nogen konkrete karakteristika. Læseren henvises 
derfor til at identificere loven ud fra dens rolle i fortællingen. Identifikationsprocessen besværliggøres imidlertid af fraværende hjælpemidler som fx en eksplicit fortællerfigur med mere eller mindre autoritative udsagn om lovens betydning eller udformning. Og det kryptiske fortælleforløb er tilsyneladende også renset for nøgler til en læse- og forståelsesesstrategi.

Som manden foran lovens dør anvises læseren ingen indlysende adgange til tekstens ubegribelige univers. Læseroplevelsen mimer således mandens frustrerende udelukkede position, hvorved tolkningsproblemet ikke blot bliver fortællingens centrale indholdsst $\varnothing$ rrelse (mandens manglende indsigt i forudsætningerne for adgang til loven), men også med provokerende påtrængenhed kommer til at dominere den tekstanalytiske forståelsesproces. Tekstanalysens traditionelle fokusering på spørgsmålet: »Hvad handler »Foran loven« om, og hvordan gør den det?« udvides derfor også til at omhandle spørgsmålet: »Hvorfor vil teksten ikke afsløre, hvad den handler om?«

Når teksten, i hvert fald for en umiddelbar betragtning, nægter at udpege egnede tydningsmodeller, henvises læseren til gætteværk. For at dette ikke skal forfalde til vilkårlighed, kræver det en kvalificering via en empirisk afprøvning af forskellige indfaldsvinklers duelighed. Artiklen her vil følgelig forsøge sig med en tekstanalytisk fremgangsmåde, der først og fremmest har til formål at fortolke »Foran loven«, men også samtidig at påpege forståelsesprocessens vanskeligheder, hvilket måske i sidste ende, som antydet, er en fortolkningsmæssig pointe.

I praksis vil følgende indfaldsvinkler til tekstens lukkede port blive inddraget i større eller mindre omfang: en samfundsmæssig, en psykologisk, en eksistentiel, en religiøs og en narratologisk. Der vil forekomme eklektiske overlapninger, da vandtætte skodder mellem de forskellige forståelsesplaner på både fortællingens og tekstanalysens niveau er en kunstig umulighed i de fem forskellige skitseringer af tolkningsmæssige tilgange til »Foran loven«.

\section{En samfundsmassig lov?}

Sammensætningen af præpositionen »Vor« (for/foran) og substantivet »dem Gesetz« (loven) i novellens originaltitel »Vor dem Gesetz« udgør begyndelsen til et bestemt og alment kendt udtryk fra det tyske sprog: »Vor dem Gesetz sind alle gleich « (For loven er alle lige). ${ }^{2}$ Titlens associative påkaldelse af det grundlæggende lighedsprincip i en demokratisk samfundsform sætter en forventning hos læseren om, at der enten kommer en bekræftelse eller en benægtelse af dette udsagn - i det mindste en problematisering af netop dette juridiske spørgsmål. 
Denne forventning kan fastholdes gennem det meste af novellen, men det kræver fra første sætning fortolkningsmæssige omskrivninger af teksten: »Foran loven står der en dørvogter « (Fl). Dørvogterens placering foran loven forlener et sprogligt og abstrakt begreb med en vis fysisk materialitet, som senere konkretiseres med betegnelserne »lovens port« og »fra sal til sal« (Fl). Samfundsmæssigt set repræsenterer loven et regelsæt for adfærden inden for et menneskeligt fællesskab, men her transformeres loven til en bygning med indgangsport og indvendig opdeling i sale.

Lovens fysiske fremtrædelsesform kan foranledige en oversættelse af begrebet til den samfundsmæssige institution til dets opretholdelse: domstolen. Mandens underforståede motiv til at opsøge loven bliver da ønsket om at forelægge en juridisk sag til prøvelse. Denne læsning kan underbygges af mandens overraskelse ved dørvogterens adgangsforbud: »Sådanne vanskeligheder har manden fra landet ikke ventet; loven må dog til enhver tid være tilgængelig for alle, tænker han« $(\mathrm{Fl})$. Manden nærer tilsyneladende en forestilling om, at for loven er alle lige. Den skuffes af dørvogterens beskrivelser af vanskelighederne ved at få foretræde for loven. Læsningen kan henvise til, at loven optræder som en social institution med en magthierarkisk (den ene dørvogter »mægtigere end den anden« $(\mathrm{Fl})$ og bureaukratisk struktur (den underste dørvogter kan end ikke udholde synet af den tredje dørvogter; dørvogteren mangler således kendskab til de øvre niveauer i den lov, han selv bevogter).

Dørvogteren er lovens repræsentant, men er ikke desto mindre uden indsigt i den lov, som han regulerer adgangen til. Når den underste magtudøvers uvidenhed kobles med lovens hierarkiske opbygning, kan det føre til en fortolkning af »Foran loven « som en lignelse om det moderne samfunds bureaukrati og uoverskuelige beslutningsformer, der fratager det enkelte menneske herredømmet over sit eget liv. ${ }^{3}$

Adskillige argumenter kan begrunde denne læsning. Vi kan begynde med novellens to figurer. Dørvogteren forholder sig til manden fra landet ligesom en af de nederste, men absolut loyale, embedsmænd i et bureaukratisk system forholder sig til en besværlig borger. Han udsteder et adgangsforbud, men giver samtidig håb om en fremtidig ophævelse: »»Det er muligt«, siger dørvogteren, »bare ikke nu«« $(\mathrm{Fl})$. En af bureaukratens fornemste dyder er de henholdende manøvrer. Hertil hører dørvogterens småforhør af manden, der kun består af »udeltagende spørgsmål« og altid slutter med meddelelsen om, at »han ikke kan lade ham komme ind endnu « $(\mathrm{Fl})$. Dørvogterens desinteresserede gennemførelse af de inkvisitoriske samtaler viser, at de ikke indebærer nogen reel mulighed for en adgangstilladelse, hvilket bekræftes af de gentagne forbud.

Dørvogterens bureaukratiske opførsel følger efter det umiddelbare indtryk af dennes udseende, som vidner om evnen til gammeldags rå magtudfoldelse. ${ }^{4}$ 
Ansigtet har barbariske træk (»sort tatarskæg «), og han advarer manden om sin fysiske styrke: »Jeg er mægtig« $(\mathrm{Fl})$. Dørvogteren er således en kombination af en brutalt udseende bodyguard og en bureaukratisk skrankepave.

Hans modspiller »en mand « introduceres kun med én enkelt angivelse af sin identitet: »fra landet « $(\mathrm{Fl})$, mens mandens navn, beskæftigelse og udseende ikke meddeles. Fraværet af identitetsgivende karakteristika bevirker, at mandens mest fremtrædende træk er manglen på individualitet. Han fremstår som en non-identitet, et X, en ingen, hvilket forskyder hans karakter fra det specifikke til det almene. Manden minder således om »Enhver« (eller »Jedermann « på tysk) fra de moralske middelalderspil, hvor denne figur blev udsat for at løbe spidsrod mellem en række personificerede begreber, syndige fristelser og retledende dyder, med et klart didaktisk sigte i forhold til publikum.

»Foran loven« ønsker i forlængelse heraf ikke at fremstille et specifikt konfliktforhold mellem en bestemt person og loven. I stedet kan novellen forstås som en generaliserende og allegorisk illustration af relationen mellem den enkelte værgeløse borger og et magtfuldt bureakratisk samfundssystem. Fortællingen udelader derfor konkrete oplysninger om sagsforløb eller retsprocedurer - faktisk er der ingen sag, ingen anklager, ingen forsvarer og ingen dom.

Den manglende konkretion i beskrivelsen af begivenhedsforløbet har som en af sine mest frustrerende konsekvenser, at adgangsforbuddet aldrig begrundes. Middelalderspillenes didaktiske anvisninger af alment moralsk rigtige handlingsmønstre, eksemplificeret i figuren »Enhver«, bliver til en modernistisk skildring af et fortabt individ i et uigennemskueligt statsapparats vold.

Loven behøver qua sin usynlighed - der er ikke én diktator med et kendt ansigt, men et uendeligt system af dørvogtere - ikke at begrunde sin magtudfoldelse. Manden kan ikke vide, hvad han gør forkert, og hvad der ville være rigtigt at gøre, hvilket leder til den antagelse, at mandens adfærd er uden betydning. Måske begrunder dørvogteren ikke sit adgangsforbud, fordi lovens magtudfoldelse i det hele taget savner begrundelse. Dette er mandens egen opfattelse af sin skæbne: »Han forbander det ulyksalige tilfælde«(Fl). Hvis årsagsforklaringer findes, er de tilslørede for både manden og læseren.

Det er denne magtens arbitraritet, der kommer til udtryk i moderne metaforer som statsapparatet eller retsmaskineriet, hvor den mekaniske betegnelse vidner om den menneskelige viljes usynlighed i et system, hvor individet kan blive kvast uden at vide hvorfor. Lovens tilfældighedsprægede magtudfoldelse understreges af mandens mislykkede bestikkelsesfors $\emptyset \mathrm{g}$ : »Manden ... anvender alt, hvor kostbart det end måtte være, for at bestikke dørvogteren« $(\mathrm{Fl})$. Med bestikkelsesforsøget demonstrerer manden en forventning om, at dørvogteren vil være modtagelig for bureaukratiets hyppige følgesvend, korruptionen. Forventningen indfris i første omgang, idet bestikkelsen accepteres, men i samme åndedrag afvises nogen garanti for en modydelse: »Jeg tager kun i- 
mod det, for at du ikke skal tro at have ladet nogen mulighed ufors $\emptyset \mathrm{gt} «(\mathrm{Fl})$. Dørvogteren er så sikker på sin magtposition, at han suverænt kan diktere nogle yderst kontroversielle spilleregler. Det enkelte individ er chanceløst i mødet med en så magtfuld lov - hvad enten allegorien gælder en institution (fx domstol eller retsvæsen) eller et bureaukratisk samfundssystem eller begge dele hvor det almindelige menneske ikke blot er afskåret fra at deltage i, men også fra at få indsigt i beslutningsprocessen, hvis den overhovedet finder sted, idet magtudfoldelsen tilsyneladende både er absolut, tilfældig og meningsløs.

Det sidste argument for at læse »Foran loven« som en allegori over en moderne juridisk eller samfundsmæssig lov - individets afmagt over for systemet - er en strukturel og tematisk forskydning i teksten. Hvis loven symboliserer domstolen, må manden have haft en sag til juridisk afgørelse. Uanset hvad loven symboliserer, har manden haft en intention med at opsøge loven - en intention vel at mærke som ikke blot har været at få adgang.

Adgangen til loven betragtes af manden som en uproblematisk og formel biting. Han beder pænt om adgang, men har ikke forventet forhindringer eller forbud: »Sådanne vanskeligheder har manden fra landet ikke ventet« $(\mathrm{Fl})$. Besværlighederne dominerer efterfølgende novellen i en sådan grad, at mandens intention med at opsøge loven forbliver en hemmelighed. Hvorfor kommer han? Hvad er hans sag? Det forbliver uopklarede og oversete spørgsmål.

I stedet for at omhandle mandens sag til fremlæggelse for loven, bliver selve adgangen til loven sagen, novellens egentlige emne. Denne tematiske forskydning kunne begrunde en samfundsmæssig synsvinkel på loven, fordi opmærksomheden i fortælleforløbet rettes bort fra en specifik sag og mod et tilfældigt adgangsforbud baseret på trusler om magtanvendelse. Hermed fokuseres på en bureaukratisk institutions tilfældige magtudfoldelse over for et enkeltindivid, som eksemplificerer situationen for »Enhver « i kontakten med domstol eller enhver anden offentlig myndighed.

Men mod novellens slutning falder hele dette eksegetiske bygningsværk sammen. Manden undrer sig umiddelbart før sin død over, at ingen andre end han har søgt indtræden i loven. Dørvogteren svarer: »Der var ingen andre end dig, der kunne få adgang her, thi denne indgang var kun bestemt for dig. $\mathrm{Nu}$ går jeg hen og lukker den« (Fl). Den samfundsmæssige synsvinkel på loven er kun holdbar indtil novellens sidste linjer, idet loven som juridisk instans bliver meningsløs, hvis dens bogstav kun angår en enkelt person. Hvis »Foran loven« skulle være en problematisering af et retsmæssigt lighedsprincip ville det fordre, at manden fra landets skæbne kunne sammenlignes med andres relation til loven. Eller i det mindste at hans historie havde en vis almengyldighed som udtryk for konflikten mellem et individ og et samfundssystem. Hans venten foran loven har ikke denne eksemplificerende karakter, da hans skæbne ikke er almen, men individuel - indgangen var kun bestemt for ham. 
Fra novellens slutning kan stort set alle argumenter for den hidtidige tolkningsmodel forsynes med det modsatte fortegn. Jeg vil ikke gendrive alle de hidtil fremsatte påstande om teksten, men nogle eksempler skal fremhæves.

Fraværet af konkrete oplysninger om sagsforløb eller retsprocedurer tjener ikke til en allegorisering af fx en bureaukratisk domstolspraksis, men beviser måske i stedet, at novellens tema slet ikke er sociopolitiske magtstrukturer. Den manglende beskrivelse af den sag, som manden medbringer til prøvelse ved domstolen skyldes formentlig, at den slet ikke findes, fordi domstolen ikke findes - loven er noget andet. At bestikkelsesforsøget mislykkes er heller ikke udtryk for lovens tilfældighedsprægede magtudfoldelse, men skyldes, at lovens ikke-sociale karakter gør den uimodtagelig for pekuniær påvirkning. Hvis novellens handlingsforl $ø$ s skulle have demonstreret uligheden for loven, skulle mandens velstand have skaffet ham en fortrinsstilling for socialkritisk at markere forskellen på fattige og rige menneskers rettigheder for loven.

Manden er således heller ikke en fortabt »Enhver « i et uigennemskueligt statsapparats vold, idet han ikke blev tilkaldt, men selv opsøgte loven, hvorfor han også har sin frihed til at forlade den. Bevisførelsen kunne fortsætte, men pointen skulle være slået fast: Novellens slutning betyder, at de i forløbsanalysen fremsatte argumenter for loven som en samfundsmæssig størrelse ved en fornyet læsning kan omvendes til en gendrivelse af denne synsvinkel.

Dette medfører imidlertid ikke, at den samfundsmæssige synsvinkel endeligt må forkastes som uanvendelig. Argumenterne kunne omvendes fra pro til contra, men de kan også tilbagevendes og omvendes igen. Selv om den samfundsmæssige synsvinkel ikke kunne udvirke en modsætningsfri helhedsfortolkning af loven, så har den alligevel sin berettigelse. Novellens juridiske anslag sender læseren afsted i dette semantiske spor efter bekræftelser på den indledende idé - bekræftelser, som indfinder sig undervejs og først tilsidst lider skibbrud. Selv om »Foran loven« derfor ikke fuldt ud bekræfter den samfundsmæssige idé, forkaster den dog heller ikke helt forestillingen.

Den samfundsmæssige forklaringsmodel har således kun begrænset gyldighed, men novellens slutning kan inspirere til en supplerende indfaldsvinkel. Ifølge dørvogterens udsagn var indgangen til loven netop bestemt for manden fra landet. Denne nødvendighed i relationen mellem dørvogteren, loven og manden fra landet leder tanken hen på noget på én gang mere individuelt og mere almengyldigt end en samfundsmæssig lov: en psykologisk lov.

\section{En psykologisk lov?}

En psykoanalytisk udlægning af »Foran loven« kunne tage sit udgangspunkt i en billedanalytisk oversættelse af det tableau, som fortællingen indledningvis 
opstiller. Der er en lov, hvis port »står åben som altid« (Fl), der er en mand fra landet, som ønsker adgang til loven, og der er en efter eget udsagn mægtig dørvogter, som udsteder et forbud mod mandens $\emptyset$ nske.

Efter en kort tænkepause kan den frejdige symboltolker præsentere sin præfabrikerede facitliste: Der fremstilles en uforløst $\varnothing$ dipal relation, hvor mandens længsel mod loven er et fantasmatisk udtryk for det regressive $\emptyset$ nske om en tilbagevenden til moderskødet (portåbningen), hvilket den straffende faderskikkelse (dørvogteren) fornuftigvis nedlægger forbud imod.

En indvending kunne være, at portåbningen ikke beherskes af et vaginalt mørke, men i stedet fungerer som lyskilde: »Men i mørket formår han nu at erkende et lysskær, der uudslukkeligt bryder frem gennem lovens dør « $(\mathrm{Fl}){ }^{5}$ Dette kan imødegås med, at loven repræsenterer moderskikkelsen i dens for barnet guddommelige fremtrædelsesform på det symbiotiske plan. Mandens længsel efter lyset er således til længslen efter den oprindelige enhed i verden før syndefaldet, efter symbiosen mellem mor og barn før adskillelsen.

Tesen om mandens adgangsønske til loven som en længsel efter den præ$\varnothing$ dipale uskyldstilstand forbliver ikke desto mindre en absurd, tekstfjern og uanvendelig konstruktion. Bortset fra døråbningen har loven ingen moderlige eller overhovedet personificerende attributter. Og hvis dørvogteren formodes at indtage faderbilledets plads i den ødipale model, hvordan skal der så redegøres for hierarkiet af fædre, der befinder sig inden for loven? Det er noget rod.

Muligvis er den ødipale trekantsmodel dog ikke håbløs, men blot forkert placeret på teksten. En moderne tekstlæser med de psykonanalytiske briller på kan vanskeligt overhøre de associationer, som udtrykket »loven« skaber til Lacans begrebsverden. En stikordsagtigt overfladisk tolkning kunne være, at novellen illustrerer mandens standsning ved overgangen til den symbolske orden = loven. Dørvogterens position som lovens repræsentant kvalificerer ham til rollen som fadernavn, men til gengæld diskvalificerer hans funktion som forbudsudsteder ham fra selvsamme rolle, idet barnets indtræden i den symbolske orden netop kendetegnes ved accepten af fadernavnet. Følgelig er dørvogteren ingen faderskikkelse, men hans egentlige rolle kan måske udledes af hans udseende: »den pelsklædte dørvogter, hans store spidse næse, det lange tynde sorte tatarskæg « $(\mathrm{Fl})$.

Det er en omfangsrig og detaljeret beskrivelse i en så relativ kort tekst, hvor novellens anden hovedpersons udseende fuldstændigt negligeres, hvorfor den analytisk set må tillægges en vis vægt. Den omfattende mængde af både dyreog menneskehår i form af pels og skæg, som omkranser ikke blot en næse, men en stor og spids næse, er en tydelig udgave af et af psykoanalysens mest populære påfund: fallossymbolet. Skægget betegnes oven i købet som tatarisk, hvilket i hvert fald inden for en europæisk kulturkreds giver mindelser om en barbarisk mennesketype fra en fjern fortid. Hvis dørvogteren således inkar- 
nerer instinktlivet, bliver »Foran loven « herefter til en fortælling om mandens problemer med at undertrykke socialt uacceptable drifter for at kunne indtræde i den symbolske orden. I kort form kunne man sige: en skildring af fortrængningens problem (manden evner ikke at skubbe dørvogteren væk) og nødvendighed (manden regrederer og dør) som betingelse for socialiseringen.

Desværre for fortolkningsmodellen, men måske heldigvis for fortællingen, findes ingen af de faktorer, som kunne begrunde en sådan læsning, i novellen. Tværtimod. Med konverteringen af dørvogteren til driftssymbol forsvinder faderskikkelsen fra novellen, mens såvel moderskikkelse som blot en antydning af spejlstadiet ligeledes er fraværende. ${ }^{6}$ Dertil kommer, at dørvogterens venlige, civiliserede og velafrettede optræden - han tilbyder manden en skammel at sidde på og konverserer ham høfligt omend uengageret - modsiger forestillingen om ham som en personificering af uregerlige instinkter.

Det psykoanalytiske begrebsapparat virker derfor demonstrativt uvedkommende i bestræbelsen på at opnå en forståelse af teksten. Alligevel har det psykoanalytiske strejftog måske ikke kun været en fortolkningsmæssig blindgyde, men også en idérig omvej. Tre resultater af den foreløbige undersøgelse kan faktisk fungere som pejlemærker for en tilnærmet helhedsforståelse. For det første synes loven at udgøre et potentiale for manden i form af en eller anden slags identitetsdannelse, der aldrig opnås. For det andet fungerer dørvogteren som modstander af mandens bestræbelser på at overskride tærsklen til rummet for denne identitetsdannelse. For det tredje repræsenterer dørvogteren måske en side af mandens personlighed, hvilket kunne føre til en forståelse af »Foran loven « som et intrapsykisk drama. ${ }^{7}$

Tesen om dørvogteren som instinktlivets inkarnation var ikke overbevisende, men selve forestillingen om dørvogteren som en side af mandens personlighed kan muligvis være perspektivrig, især hvis den analytiske fremgangsmåde bliver mindre begrebs-rigoristisk end hidtil.

Novellens slutning fastlægger mandens og dørvogterens indbyrdes bånd: »denne indgang var kun bestemt for $\mathrm{dig}_{\text {« }}(\mathrm{Fl})$. Både loven og dørvogteren eksisterer kun for denne bestemte mands skyld. Når manden forbander »det ulyksalige tilfælde « er det et udtryk for en fuldstændig misforståelse af sin situation. Adgangsforbuddet er ikke noget udslag af et administrativt bureaukratis travlhed. Loven er »bestemt« for ham, ergo er forhindringen også hans.

Manden fra landet gør sig således skyld i en fatal kategorifejltagelse ved mødet med loven: »loven må dog til enhver tid være tilgængelig for alle, tænker han « $(\mathrm{Fl})$. Manden tror, at det er en samfundsmæssig og almengyldig lov, men loven afslører sig senere som en personlig og psykologisk lov.

I forlængelse heraf kan mysteriet om den udeblivende adgangstilladelse måske opklares. Den døende mands sidste spørgsmål kommer for sent: »»Alle stræber dog efter loven, « siger manden, »hvordan kan det da være, at jeg er 
den eneste, der har bedt om adgang i alle disse år?«« (Fl). Efter alle de utallige spørgsmål, som manden i tidens løb har trættet dørvogteren med, stiller han tilsidst det rigtige: »Hvem er jeg? « - til forskel fra de andre.

Loven rummer måske svaret på denne identitetsmæssige gåde, hvilket kan underbygges af dens indretning. Dørvogteren bemærker om sin egen position: »Jeg er mægtig. Og jeg er kun den underste dørvogter; fra sal til sal står der dørvogtere, den ene mægtigere end den anden « $(\mathrm{Fl})$. Dette er en nærmest mytisk eller eventyragtig konfiguration af personlighedsudviklingen som en række prøvelser med stadigt stigende sværhedsgrad. Og betegnelsen »underste « placerer dørvogteren som den nederste i et magthierarki, men indikerer derfor samtidig et begyndelsespunkt på en vertikal og etagelignende struktur inden for loven, hvilket korresponderer med stadierne i en åndelig eller erkendelsesmæssig udvikling. ${ }^{8}$

Hertil svarer det fra loven frembrydende lysskin, som er en fra de antikke grækere og til i dag kendt metafor for visdom og selvindsigt. Mandens projekt med at opsøge loven er således at finde sig selv. Årsagen til mandens ankomst til loven kan søges i hans tilnavn »fra landet « $(\mathrm{Fl})$. Denne betegnelse associerer til en beskæftigelse som bonde, hvilket implicerer en forholdsvis problemfri identitetsdannelse bestemt af prædisponerende slægts- og samfundsmæssige bånd. Identitetskonflikter er i den vestlige kulturhistorie tæt forbundet med urbaniseringen og den sociale mobilitet.

Mandens landlige herkomst antyder, at hans hidtidige tilværelse har udspundet sig i et miljø, hvor kravet om en selvstændig personlighedsudvikling er relativt lidt påtrængende. Især set i relation til tidspunktet for novellens tilblivelse (1914), hvor moderniteten stadig primært var et byfænomen, mens den agrare livsverden endnu overvejende var traditionsbestemt. Alt hvad novellen fortæller om mandens fortidige liv er, at han tilsyneladende med dygtighed har tilpasset sig samfundets fordring til en duelig borger, hvilket har resulteret $\mathrm{i}$ en vis $\varnothing$ konomisk velstand: »Manden, der har udrustet sig godt til rejsen, anvender alt, hvor kostbart det end måtte være, for at bestikke dørvogteren « (Fl). Mandens arbejdsliv har således været en succes, men muligvis har denne ydre sociale tilpasningsdygtighed været koblet med store, indre og personlige omkostninger. Hvis denne formodning er korrekt, kan dørvogteren og loven forstås som en sindbilledlig tilsynekomst af psykiske dimensioner, som hidtil har været fortrængt i mandens liv. Det intrapsykiske drama, som teksten fremstiller, kan ud fra denne synsvinkel diagnosticeres som en midtlivskrise.

Loven repræsenterer mandens potentiale for udviklingen af en selvstændig personlighed, dørvogteren repræsenterer mandens psykiske modstand mod den nødvendige selverkendelse. Dennes nødvendighed fremgår af konsekvenserne ved mandens manglende evne til indtræden i loven, som er en infantil regression (manden går »i barndom $\ll(\mathrm{Fl}))$ og døden. 
Flere argumenter kan begrunde denne hypotese om lovens psykologiske karakter. De manglende oplysninger om mandens fortid, hans familiemæssige baggrund og ikke mindst hans navnløshed peger i retning af en fraværende personlighed. Det signalerer den totale identitetsløshed, at manden ikke kan foretage den basale sproghandling, der er forudsætningen for en singulær menneskelig eksistens: »Jeg er/hedder Kaare « - med den underforståede betydning af $»$ til forskel fra Franz, Max og Ernst $\ll .{ }^{9}$

Hvis loven rummer hemmeligheden om mandens eksistens, kan det metaforisk siges, at bag døråbningen er hans navn skrevet. ${ }^{10}$ Navnet ligger kun og venter på, at han henter det. Her ligger også svaret gemt på, hvorfor manden på trods af sin årelange, resultatløse ventetid aldrig forlader loven. Det kan han ikke, fordi både loven og dørvogteren dybest set findes inde i ham selv.

Over indgangsporten til loven kunne være skrevet det antikke delfiske orakelord, men forstået i dets moderne psykologiske betydning: »Kend dig selv«. Manden viger tilbage for dette påbud om selvindsigt. Hans hidtidige liv på landet har åbenbart ikke forsynet ham med de tilstrækkelige forudsætninger for at forstå hverken lovens budskab eller betingelserne for at få adgang: »Sådanne vanskeligheder har manden fra landet ikke ventet $\ll(\mathrm{Fl})$.

Mandens fejltagelse er at se loven og dørvogteren som fremmede og tilfældige forhindringer i stedet for som personlige og uomgængelige tærskler i en psykisk erkendelsesproces. Hvis dørvogteren anskues som den psykiske modstander af den nødvendige selverkendelse - som et kompleks eller traume, udsprunget af opdragelse og opvækstvilkår - bliver det klart, hvorfor mandens løsningsmodeller er virkningsløse. Bestikkelsesforsøget får kun komplekset til at vokse, hvilket konkret demonstreres med, at størrelsesforholdet på de to figurer ændrer sig »i mandens disfavør« $(\mathrm{Fl}) . \mathrm{Og}$ beslutningen om at vente på adgangstilladelsen er ligeledes håbløs, idet dørvogteren inkarnerer en selvdestruktiv side af mandens egen personlighed, som vil findes, ligeså længe manden selv findes. Medmindre manden tager skridt til at fjerne forhindringen, hvilket han aldrig gør. Årsagen til hans kummerlige endeligt er, at han ved sin manglende forståelse af lovens personlige natur og sin deraf følgende passive handlemåde overdrager ansvaret for sin udelukkelse fra loven til dørvogteren.

I stedet for at vende blikket indad mod sin egen ansvarlighed accepterer manden uden sværdslag adgangsforbuddet. Mandens højlydte forbandelser af »det ulyksalige tilfælde« (Fl) forbliver impotent brokkeri, fordi det aldrig opfølges af handling. Fortællingen lader det således være et uopklaret spørgsmål, om dørvogterens fysiske styrke er mandens overlegen, og endog om dørvogteren overhovedet ville have modsat sig et fors $\emptyset \mathrm{g}$ fra manden på at tiltvinge sig adgang.

Psykologisk set er manden selv ansvarlig for at tildele sin kompleksbetonede modstand mod selverkendelsen dens uovervindelighed. ${ }^{11}$ Ved sin passive 
ansvarsforflygtigelse opbygger han dørvogteren som en uoverkommelig modstander, hvilket efterhånden bliver en barriere for hans forståelse af sit projekts erkendelsesmæssige beskaffenhed: »I de mange år iagttager manden næsten uafbrudt dørvogteren. Han glemmer de andre dørvogtere, og denne første forekommer ham at være den eneste hindring for hans adgang til loven « (Fl).

Ved at fokusere al sin opmærksomhed på dørvogteren stirrer manden sig blind på kompleksets overmagt frem for at finde midler til dets overvindelse. Hans minutiøse overvågning af dørvogteren som bæreren af hemmeligheden det adgangsgivende »sesam, sesam, luk dig op« - blokerer for hans opdagelse af loven med dens befriende og personlighedsudviklende potentiale. Han lader sig styre af sit kompleks frem for omvendt.

Manden fra landet er således i egentligste forstand ikke herre i sit eget hus, dvs. i sin egen psyke. Ikke blot er han ikke herre i sit eget hus, han står faktisk uden for det og forhindrer sig selv $i$ at få adgang ved at tildele en indre psykisk fangevogter status som en ydre og uforklarlig modstander. Mandens ængstelige tøven foran døren til sin fødsel som en selvstændig personlighed gør fortællingen til en nærmest arketypisk afbildning af en mislykket individuationsproces.

For en umiddelbar betragtning kan dørvogterens beskaffenhed vanskeligt konkretiseres. Han kan siges at repræsentere alle former for hæmninger i livsudfoldelsen, forårsaget af nederlagsbetonede oplevelser, måske primært i opvæksten, som i tidens løb har sammenføjet sig til en tilsyneladende uovervindelig psykisk blokering for den videre livs- og personlighedsudvikling; dørvogteren inkarnerer et skræmmende og dundrende »du kan og må ikke...! «

Det ville imidlertid fra en værkorienteret synsvinkel være bekvemt at foretage en kobling tilbage til dette kapitels indledende psykoanalytiske analysefors $\varnothing \mathrm{g}$ og beholde dørvogteren som en truende faderskikkelse, da denne figur har en fremtrædende placering i adskillige af Kafkas både udgivne og efterladte skrifter. ${ }^{12}$

»Foran loven « rummer ingen skildringer af mandens barndom eller familiemæssige baggrund, men alligevel lader bekvemmeligheden sig måske begrunde ved en iagttagelse af hans handlingslammelse. På trods af den årelange ventetid forsøger manden på intet tidspunkt at bryde adgangsforbuddet, hvilket tyder på en umådeholden og næsten grotesk tålmodighed. Hvis loven rummer et navn- og identitetsgivende potentiale, udgør mandens adfærdsmønster et skræmmende eksempel på en overdreven selv-fornægtelse og selv-undertrykkelse, hvilket tilsidst har sin konsekvens i den totale selv-udslettelse.

Denne autoritetsforskræmte lydighed antyder tilstedeværelsen af et uhyre dominerende over-jeg, respektivt et internaliseret og prohibitivt faderimago. Den reale faderskikkelses fravær kunne forklare dørvogterens mægtighed, idet den internaliserede faderfigur som selvstændiggjort kompleks ikke kan rela- 
tiveres i sin omnipotens af dens forbillede fra virkeligheden. Mandens tilpasningsivrige adlyden af omverdenens krav kunne således indikere, at dørvogtermodstanderen i den mislykkede individuationsproces repræsenterer et internaliseret og derfor magtfuldkomment faderbillede.

Tilsyneladende kan det bud på en psykologisk forklaringsmodel, som nu er oprullet, i højere grad end den samfundsmæssige synsvinkel danne udgangspunkt for en helhedsforståelse af »Foran loven«. Men hele fortolkningen bygger på en uudsagt præmis: gyldigheden af at oversætte de konkrete tekstelementer til en psykologisk forståelsesramme, som strukturelt og forløbsmæssigt kan begrundes, men som ikke har nogen nagelfast forankring i novellens overfladeniveau. For eksempel kunne argumentet med den fraværende reale faderskikkelse omvendes, så det ikke støttede hypotesen om et internaliseret faderimago. I stedet kunne fraværet af faderskikkelsen, den manglende skildring af mandens familiemæsssige baggrund og hans fortid i det hele taget være et argument for, at den psykologiske forklaringsmodel ugyldiggøres af en utilstrækkelig tekstnærhed. Dette synspunkt kan måske bekræftes af en udviklingstendens i Kafkas forfatterskab.

Kafka interesserede sig for psykologien, bl.a. Freud, hvilket ses af dagbogsbemærkningen ved produktionen af $»$ Dommen $\ll,{ }^{13}$ som udgjorde et slags initierende gennembrud i forfattergerningen ved at være det første værk, der gav en tilfredsstillende oplevelse af skriveprocessen som erkendelsesgivende. Og det ses af hans tilsyneladende freudiansk inspirerede biografiske tolkning af »Dommen «, hvor han via sammenfald i ordlængde og stavemåde oversætter fiktionsfigurernes navne til sit eget forlovelses- og familiedramas navne, som om de var pseudonymer for virkelighedens psykiske konfliktstof. ${ }^{14}$

Senere fik han imidlertid en stærkt negativ indstilling til psykologisk orienterede forklaringsmodeller, hvilket kan aflæses af to notater fra Oktavhefterne: »Psykologi er læsning af en spejlskrift, altså besværlig, og hvad det altid stemmende resultat angår, udbytterig, men i virkeligheden er der intet sket«. Og det berømte kampråb mod psykologien: »For sidste gang psykologi! « ${ }^{15}$

Her betragtes den psykologiske beskrivelsesmåde som en forførende, men overfladisk metafysik, der ikke for alvor er i stand til frembringe ny erkendelse. Denne afstandstagen fra den psykologiske synsvinkel som indsigtsbefordrende korresponderer med den udvikling, man kan iagttage mellem de tidlige tekster »Dommen « (skrevet 23. sept. 1912) og »Forvandlingen« (skrevet nov.-dec. 1912) og de senere Processen og »Foran loven«, hvor de psykologiske faktorer mere eller mindre er renset ud af teksten. Josef K.'s familiebaggrund fortælles stort set ikke, ligesom manden fra landet familiemæssigt set befinder sig i et limbo.

At den psykologiske synsvinkel måske ikke interesserede forfatteren deklasserer den selvfølgelig på ingen måde som forklaringsmodel. Den kan sag- 
tens være at finde i teksten alligevel. Det må imidlertid mane til besindighed, at den psykologiske indfaldsvinkel ikke har noget direkte anknytningspunkt i »Foran loven«, særskilt hvis dette kan forbindes med en tematisk udvikling i forfatterskabet bort fra skildringen af psykologisk konfliktstof. På denne baggrund må der derfor siges at være sået berettiget tvivl om den anklagedes (tekstens) skyld, selv om en helhedsfortolkning af »Foran loven« tilsyneladende kan baseres på en oversættelse til et psykologisk symbolsystem. Denne synsvinkel kan således hverken betragtes som udtømmende eller enerådende.

Fraværet af baggrundsstoffet for manden fra landets psykologiske profil kunne afsætte den mistanke, at teksten snarere end en specifik psykologisk tematik søger at skildre et alment eksistentielt problem. En idé herom kunne måske opstå med en eksistensfilosofisk indgangsnøgle som endnu et fors $\varnothing \mathrm{g}$ på at dirke novellens tilslørede dør op.

\section{En eksistentiel lov?}

Af de to foretagne læsninger vil en eksistentiel tolkning lægge sig i forlængelse af den psykologiske. Der kan tænkes mindst to modsatrettede udlægninger af loven som en eksistentiel instans, hvilket skal skitseres i det følgende - den første med inspiration fra eksistensfilosofiens stamfader, Kierkegaard, og den anden med inspiration fra den ateistiske eksistentialismes frontfigur, Sartre.

Før udpegningen af forskelle på de to eksistentielle indfaldsvinkler kan deres fælles anknytningspunkt til novellen antydningsvist bestemmes. Manden fra landet konfronteres ved sin ankomst til loven med dørvogterens indgangsforbud, hvilket sætter ham i en valgsituation, en eksistentiel grundkategori.

Manden har tre valgmuligheder: at trodse forbuddet, at acceptere forbuddet, at forlade loven. Han vælger tilsyneladende at vente. Af angst for dørvogterens barbariske og magtfulde fremtoning »beslutter han sig alligevel til at vente, indtil han får indgangstilladelsen « $(\mathrm{Fl})$. Ved at foretrække ventepositionen overdrager manden ansvaret for sin skæbne til dørvogteren. Han prøver at vælge ikke at vælge.

Den tilsyneladende beslutningsdygtighed i udtrykket »beslutter han sig « afsvækkes af det følgende »alligevel«, der klargør, at ønsket om at vente mere er et udslag af en ængstelig føjelighed over for en ydre forhindring end udsprunget af en indre tilskyndelse. At manden foretrækker ventepositionen behøvede ikke nødvendigvis at være et udtryk for fralæggelse af personligt ansvar, men det ville fordre, at manden opfattede det at vente som et inderliggjort valg. At dette ikke er tilfældet fremgår af hans adfærdsmønster: »Han gør mange forsøg på at blive lukket ind og trætter dørvogteren med sine bøn- 
ner « $(\mathrm{Fl})$. Manden sætter sig ikke tålmodigt til at vente i overbevisningen om at have gjort det rette valg. Tværtimod, med bestikkelse og bønner går han tiggergang hos dørvogteren. Ventepositionen er et angstbetonet fravalg af selvbestemmelse, ikke et personligt tilvalg.

Mandens højeste og eneste ønske er at få adgang til loven, men hans passive handlemåde forhindrer dets opfyldelse. Ved denne selvmodsigelse sætter manden sig selv skakmat. Manden formår således hverken at foretage en personlig tilegnelse af den skæbne, som forekommer ham uomgængelig, ${ }^{16}$ et amor fati, eller at tage skridt til en forandring.

Denne handlingslammelse - $\mathrm{i}$ udspændtheden mellem et fastholdt adgangsforbud og et ufravigeligt adgangsønske - kombineret med uvilligheden til at acceptere ventepositionen (som selvvalgt) kunne med Kierkegaard kaldes for manglende inderlighed, mens Sartre ville klandre manden for uredelighed. »Foran loven« kan således beskrives som omhandlende et eksistentielt dilemma. Karakteren af dette dilemma vil blive søgt indkredset med en kortfattet fremstilling af henholdsvis en religiøs og en ateistisk tolkning.

Den psykologiske indfaldsvinkel til »Foran loven« sandsynliggjorde, at mandens formål med at opsøge loven var at finde sig selv. En Kierkegaard-inspireret tolkning af novellen kan tage sit udgangspunkt heri, blot med den vigtige forskel, at selverkendelse ikke er en psykologisk, men en religiøs proces: »Når mennesket vender sig mod sig selv, vender det sig samtidig mod Gud selverkendelse er ét med Gudserkendelse $\ll .{ }^{17}$

Ud fra denne religiøst-eksistentielle opfattelse ligger det lige for at opstille hypotesen om loven som, ikke Gud, men vejen dertil: troen. Adskillige argumenter kan begrunde denne idé. Det fra loven frembrydende lys kan repræsentere den mulighed for initiation til en religiøs virkelighed, som manden aldrig indfrier. ${ }^{18}$ Hans udelukkelse skyldes hans indstilling: »loven må dog til enhver tid være tilgængelig for alle, tænker han « $(\mathrm{Fl})$. Forudsat at loven er den religiøse tro, så er denne netop ikke åben for alle og enhver, men kun for hin enkelte hver for sig. ${ }^{19}$ Erhvervelsen af troen er et individuelt og personligt anliggende, men mandens strategier for at vinde adgang til loven demonstrerer en total misforståelse af dette eksistentielle grundvilkår. Da dørvogteren træder til side og derved lokker manden til at tilsidesætte indgangsforbuddet, træder han ikke ind gennem den åbne port, men bukker sig »for at se hvad der er indenfor « $(\mathrm{Fl})$. Dette udtrykker et forsigtighedens $\emptyset$ nske om at få vished for, hvad der findes inden for loven som forudsætning for eventuelt at foretage det risikofyldte valg at overskride dørtærsklen.

Troen står imidlertid i et modsætningsforhold til visheden. Troen fordrer vovemod og villighed til at løbe en risiko. ${ }^{20}$ Den kan ikke udstede nogen salighedsgarantier, eftersom det ville gøre troen til en fornuftsbetonet byttehandel, 
ikke til en inderlig tilegnelse foretaget i objektiv uvished: »Dersom Det jeg ved at vove skal komme i Besiddelse af er vist, saa vover jeg ikke, saa bytter jeg. $\ll^{21}$

Når manden fra landet anvender alle sine værdier »for at bestikke dørvogteren « $(\mathrm{Fl})$ inkarnerer han denne kræmmermentalitet i forhold til religiøsiteten. Han forestiller sig, at han kan købe sig en risikofri adgang til troen. Derved glemmer han den vigtigste forudsætning for troen: subjektiviteten. Dette fremgår både af hans relation til loven og hans adfærd over for dørvogteren. Manden fra landet er generelt intellektbetonet i sin tilgang til lovens hemmelighed, hvilket ses af hyppigheden af vidensrelaterede gloser i teksten: »tænker sig om «, »tænker «, »ser nærmere på «, »iagttager «, »studium «, »ved ikke « (Fl). Denne ophobning gennem teksten kulminerer i dørvogterens reaktion på mandens ønske om at stille et sidste spørgsmål: »»Hvad vil du nu have at vide?» spørger dørvogteren, »du er umættelig «« (Fl, min understregning).

Dørvogterens formulering viser, at mandens spørgetrang beherskes af forestillingen om at finde en fornuftsbestemt adgang til loven. Hans idelige studier af dørvogterens fremtræden udtrykker ligeledes $\varnothing$ nsket om at opdage en objektiv indgangskode til loven. Det ufrugtbare ved denne fremgangsmåde fremgår af dens meningsløse resultat: den tragikomiske opdagelse af »lopperne « $(\mathrm{Fl})$ i dørvogterens pelskrave, som manden forgæves beder om hjælp. Troen kan således ikke erhverves ved en distanceret iagttagelse og undersøgelse, ved en akkumulation af rationel viden. Den udgør en hemmelighed, som ikke har noget 'password'. Den fordrer et spring ud i uvisheden, et subjektivt valg af en livsanskuelse, som transcenderer grænserne for den objektive erkendelse.

Set i lyset af denne formodning om lovens karakter iscenesætter manden fra landet allerede ved sin ankomst sin egen udelukkelse, idet han »beder om adgang til loven « $(\mathrm{Fl})$. Allerede ved at stille spørgsmålet om adgang berøver manden sig muligheden herfor, idet han overdrager ansvaret til dørvogteren. I dørvogterens svar på mandens anmodning ligger en dobbelttydighed, som kan understøtte denne tolkning: »Men dørvogteren siger, at han ikke kan give ham tilladelse til at træde ind $n u$ « $\mathrm{Fl}$, min understregning). Denne formulering gentages på mandens næste spørgsmål, om han senere kan få adgang: »»Det er muligt», siger dørvogteren, »bare ikke $и и « «(F l$, min kursivering).

Hvis adgangsforbuddet ikke skal ses som et udslag af »det ulyksalige tilfælde « $(\mathrm{Fl})$, da kan den gentagne tidslige angivelse »nu « tolkes, ikke som en vilkårlig bestemmelse, men som henførende til og en konsekvens af mandens spørgsmål. Den underliggende betydning af dørvogterens udsagn bliver herefter: »Nu (hvor du har spurgt), kan du ikke komme ind. « Selve ønsket om en indgangstilladelse fremkalder således forbuddet.

At mandens passivitet forårsager udelukkelsen fra loven korresponderer også med forhørsseancernes »udeltagende spørgsmål «(Fl), idet spørgsmåle- 
nes overfladiskhed indikerer, at de ikke udgør en optagelsesprøve, som manden kunne bestå med en korrekt besvarelse. Dørvogteren kan ikke tildele manden adgang, idet denne indgang til loven kun er »bestemt « for netop denne mand. Det betyder, at loven eller troen er en udelukkende personlig mulighed, som kun kan realiseres af manden fra landet på hans egne præmisser - det er op til ham at afgøre hvordan og hvornår.

Denne selvstændige afgørelse angår opfyldelsen af en bestemmelse, som tilsyneladende på forhånd er givet, hvilket stemmer overens med en religiøsteksistentiel synsvinkel, idet menneskets opgave er i frihed at vælge en guddommeligt prædestineret bestemmelse: ved at vælge troen forstår mennesket sig selv som et evigt og åndeligt væsen i mødet med den Gud, der har skabt det. $^{22}$ Til gengæld stemmer denne forestilling om mennesket som havende en delvis guddommeligt determineret bestemmelse meget dårligt overens med en ateistisk-eksistentiel synsvinkel. Mens religiøse tænkere (selv Kierkegaard) groft sagt mener, at menneskets frihed er gudsgiven, hævder ateistiske eksistentialister (Camus, Sartre), at menneskets frihed konstitueres af Guds fravær.

Der findes enkelte argumenter for at udlægge »Foran loven« som et eksempel på denne opfattelse. Ifølge Camus udspringer eksistensens absurditet af forholdet mellem menneskets higen efter en absolut mening med livet og universets irrationelle meningsløshed: »Det absurde opstår af mødet mellem menneskets kaldende råb og universets meningsløse tavshed. $\ll^{23}$ For en umiddelbar betragtning kunne Kafkas novelle tages som et kondenseret sindbillede på absurditeten som et menneskeligt grundvilkår. Hvis mandens higen efter loven er udtryk for en erkendelsesmæssig søgen, så fremtræder denne søgen som resultatløs. Manden øder størstedelen af sit liv bort på et råb om mening, som aldrig besvares. Derved opstiller han loven som en absolut størrelse, der kan tildele ham en a priori givet mening med eksistensen. I modsætning hertil vil eksistentialismen erindre mennesket om, »at der ikke er anden lovgiver end han selv. $\ll^{24}$ At manden klynger sig til loven, ja at han i det hele taget har opsøgt loven i håbet om at finde en allerede defineret overindividuel mening, er et udtryk for en flugt fra dette eksistentielle vilkår. Hans handlemåde afslører en angst for den eksistentielle frihed, som indebærer et krav om, at individet selv er anvarligt for at konstruere værdierne i sin væren og verden.

Herimod kunne indvendes, at manden dog tilsidst ser et frembrydende lys fra loven, hvilket virker som en bekræftelse på dens gyldighed. Det er imidlertid en tvivlsom ontologisering af lovens status, hvis man tager den foregående sætning i betragtning: »Til sidst svækkes hans syn, og han ved ikke, om det virkelig bliver mørkere om ham, eller det kun er hans øjne, der bedrager ham« (Fl). Loven fremtræder tilsyneladende som et fata morgana, som et illusorisk blændværk. Det kan i det mindste ikke med sikkerhed afgøres, om manden 
næsten i dødsøjeblikket ser glimtet af en transcendent sandhed, eller om hans $\varnothing j n e$ bedrager ham. Hvilket understøtter tesen om »Foran loven « som en tekst der tematiserer det formålsløse i at søge eksistensens mening i en uden for mennesket liggende overvirkelig instans, som, hvis den findes, under alle omstændigheder alligevel ikke kan give den søgende den $\emptyset$ nskede bekræftelse.

Denne ateistisk-eksistentielle og desillusionerede udlægning af lovens status undermineres imidlertid af dørvogterens afsluttende udsagn: »thi denne indgang var kun bestemt for dig «(Fl). Dette udsagn kan betvivles, idet dørvogteren allerede ikke kan udholde synet af den tredje af sine kolleger, hvorfor han åbenbart har en begrænset viden om loven. Men hans udsagn om indgangens bestemmelse for manden sandsynliggøres af, at ingen andre i alle årene har opsøgt dette sted..$^{25}$ Dertil kommer, at manden på trods af sit svigtende syn, ikke bare ser, men - med en stærkere glose - »erkende[r] et lysskær, der uudslukkeligt « $(\mathrm{Fl})$ vælder frem fra lovens dør. Meget tyder således på, at manden opnår en form for åbenbaring af lovens eksistens umiddelbart før sin død. ${ }^{26}$

I forlængelse heraf virker den ateistisk-eksistentielle synsvinkel i det mindste tvivlsom, men den religiøst-eksistentielle synsvinkel efterlader også en række ubesvarede spørgsmål som fx.: Hvad er dørvogterens funktion? Hvorfor spærrer han manden vejen til dennes bestemmelse? Hvis loven er troen, hvilken tro er der så tale om? Hvorfor er der flere dørvogtere inden i loven?

Den eksistentielle fortolkningsmåde er i det hele taget primært anvendelig i forhold til at undersøge mandens indstilling over for at få adgang ved loven, hvorimod den ikke kan udvirke en helhedsforståelse af alle tekstens elementer. Til gengæld er den klar i sin udpegning af mandens fejltagelse: »... det er ikke muligt at lade være med at vælge ... hvis jeg ikke vælger, så vælger jeg alligevel. « $\ll^{27}$

Manden har valgt, at han ønsker at få adgang til loven, men dette valg følges aldrig af en handling. Det forbliver derfor en gåde, hvordan forløbet havde været, hvis manden havde fors $\emptyset \mathrm{gt}$ at trodse adgangsforbuddet. Ville dørvogteren med magt have modsat sig mandens indtræden? Var han veget til side? Er dørvogteren så mægtig, som han selv påstår? Ville manden være sluppet ind i loven? Disse spørgsmål kan ikke besvares af teksten, men en idé herom kan opnås fra et fragment, som Max Brod fandt i Kafkas efterladte skrifter og i en note betegnede som en variant til »Foran loven $\ll^{28}$

»Jeg løb forbi den første vogter. Bagefter blev jeg forskrækket, løb igen tilbage og sagde til vogteren: »Jeg løb forbi her, mens du kiggede den anden vej.« Vogteren så hen for sig og tav. »Det skulle jeg vel ikke have gjort, « sagde jeg. Vogteren tav stadig. »Betyder din tavshed, at jeg har tilladelse til at passere $? \ll \ldots \ll^{29}$ 
Grundbilledet er det samme i novelle og fragment, men figurernes reaktion og resultatet er forskellige. I fragmentet sikrer jegets handlekraft, at det passerer den første vogter, hvorimod manden i »Foran loven« aldrig kommer så langt.

Denne forskel antyder muligvis, at manden fra landet selv kunne bære ansvaret for sin udelukkelse fra loven. ${ }^{30}$ En formodning der kan underst $\varnothing$ ttes af det videre forl $\varnothing \mathrm{b}$ i fragmentet, hvor vogteren ikke gør ansats til at standse jeget eller til at straffe jeget for dets indtræden uden forudgående adgangstilladelse. Tværtimod er det jeget selv, som efterfølgende får bondeanger og konstruerer en forseelse og en skyld (»Det skulle jeg vel ikke have gjort«), som han derefter søger bekræftelse på hos den tavse vogter.

Det indtrædende jegs frihedskonstituerende handling bliver efterlods angstprovokerende, som om han skræmmes ved friheden til selv at formulere adfærdsreglerne og moralen i sin verden. Han skræmmes ved udsigten til at være sin egen lovgiver, men konverterer denne angst til en frygt for vogteren. Han iscenesætter således selv den passive vogter som en magtfuld autoritet. Måske placerer jeget i fragmentet derved sig selv i en evig spørge- og venteposition ligesom manden fra landet $\mathrm{i} »$ Foran loven «. Og måske kunne manden fra landet have fået adgang til loven, hvis han havde brudt adgangsforbuddet. ${ }^{31}$

Dette forbliver mere eller mindre velbegrundede spekulationer, eftersom spørgsmålene ikke kan besvares af teksten. Det er også begrænset, hvor mange spørgsmål de to eksistentielle synsvinkler har kunnet besvare. Til gengæld har de foranlediget ny tvivl, fordi de udgør to forklaringsmodeller, der gensidigt udelukker hinanden, men som ikke desto mindre begge har en vis sandsynlighed. Denne paradoksale tvetydighed har dog et dominerende fællestræk: opfattelsen af, at manden fra landet viger tilbage for at vælge, der tildels er samstemmende med den psykologiske synsvinkel. Men hvilke muligheder har manden faktisk for at vælge? Dette og andre spørgsmål kan måske besvares eller give anledning til yderligere tvivl om tekstens mening - med hypotesen om loven som en specifik religiøs lov.

\section{En religiфs lov?}

Et af problemerne for både den psykologiske og den eksistentielle forklaringsmodel var at foretage en identificering af loven $\mathrm{i} »$ Foran loven $«$. Betydningen af begrebet måtte udledes indirekte. For en umiddelbar betragtning behøver hypotesen om loven som en religiøs instans ikke en udledning af denne art. Franz Kafka var som bekendt af jødisk herkomst, ${ }^{32}$ og: »I den græske oversættelse af Gl. Test. fra det 2. årh. f. Kr. oversættes det hebraiske tora, der endnu stedvis betyder Guds befaling eller viljesbud, slet og ret ved nomos (loven). $\ll^{33}$ 
Der findes adskillige argumenter for denne udlægning. Metaforiseringen af loven som en bygning er en kendt konceptuel tradition i jødedommens skrifter. ${ }^{34}$ Den arkitektoniske udformning af loven associerer endvidere til Toraens opbevaringssted, templet, hvis indgang blev overvåget af dørvogtere. Deres opgave bestod bl.a. i at påse, at ingen urene kom ind gennem tempelporten. ${ }^{35}$

Disse foreløbige betragtninger over dørvogteren som repræsentant for en religiøs virkelighedsopfattelse har imidlertid også kun interesse, hvis de kan sandsynliggøres af den egentlige prøvesten for hypotesen om loven som Toraen: dens anvendelighed som analytisk redskab i frembringelsen af en tilnærmet helhedsforståelse af novellen.

Der kan tænkes flere, og indbyrdes modstridende fortolkninger, hvilket skal skitseres i det følgende. Det første spørgsmål, der kunne stilles til novellen, er om mandens udelukkelse fra loven forårsages af en manglende efterlevelse af lovens bud. I Toraen findes 613 bud, som udtrykker Guds vilje i forhold til jordelivets indretning, hvad angår fx omskærelse, overholdelse af sabbaten, etiske fordringer, spiseregler og renlighedsforskrifter. Der findes i jødedommen derfor ikke den dualistiske opdeling af verdensbilledet i det himmelske og det jordiske, det hellige og det profane, som kendetegner kristendommen, idet retningslinjerne for den dennesidige tilværelse er religiøst indstiftede. Mens kristendommen primært grundes på bekendelse, er jødedommen i højere grad praksisbestemt. ${ }^{36}$ Hele tilværelsen er i princippet en ritualiseret realisering af nogle religiøse forskrifter, hvor hver enkelt troende menneske i kraft af sin lovlydige livsførelse bidrager til, at Guds vilje både med universet og den enkeltes liv gennemføres. Overholdelsen af loven sikrer ikke kun den enkelte frelsen i form af opstandelsen, men medvirker også til opretholdelsen af universets orden: »Der er mening, fordi vores eksistens er direkte og nært engageret i opfyldelsen af et guddommeligt formål «. ${ }^{37}$

Menneskelivet har i forlængelse heraf kun mening og værdi, sålænge det udfolder sig efter loven. I relation til »Foran loven« kunne manden fra landets fejltagelse herefter være at opsøge loven som et fra hverdagslivet adskilt tilbedelsesobjekt - næsten som en katolsk munk afsondrer sig fra det profane liv for desto bedre at kunne tage del i det hellige. Manden længes efter det hellige som en lokalitet, hvor han kan lukkes ind, i stedet for at lukke det hellige ind i sit liv som en grundlov for eksistensen. Dette kan ud fra jødedommen betragtes som en syndig foreteelse, fordi manden forsøger at forlade det tilværelsesrum, som Gud har stillet til rådighed for menneskene, hvor den troende ellers skulle virke som Guds forlængede arm ved med sin lovbestemte livsførelse at bidrage til det skaberværk, som Gud påbegyndte med Genesis. ${ }^{38}$

Denne tolkning kolliderer imidlertid med dørvogterens afsluttende konstatering af, at indgangen var bestemt for manden fra landet. Hans ankomst til 
loven er en reel forfølgelse af hans tilsyneladende prædestinerede bestemmelse. Mandens problem er blot hans ukendskab til den bestemmelse, som han alligevel bærer inden i sig, og som delvis styrer hans handlinger. Han har således formået at opsøge sin indgang til loven, selv om hans udvandede motivation herfor er, at »Alle stræber dog efter loven« $(\mathrm{Fl})$.

Årsagen til mandens udelukkelse fra loven kunne herefter søges i hans utilstrækkelige forberedthed, hans manglende indsigt i sin bestemmelse og forudsætningerne for at opnå den, hvilket kan understøttes af hans overraskelse ved mødet med forbuddet: »Sådanne vanskeligheder har manden fra landet ikke ventet; loven må dog til enhver tid være tilgængelig for alle, tænker han« (Fl). Denne mulige uvidenhed om lovens adgangskriterier ekspliciteres ikke i fortællingen, hvorfor den kan tænkes at være alt lige fra det helt konkrete - at manden ikke kender de nødvendige renselsesritualer for indtræden i det hellige rum, og at han som uren spærres adgang - til det metafysiske - at manden ikke er tilstrækkeligt åndeligt forberedt til at opnå en religiøs erkendelse.

Denne formodning kan underbygges af, at betegnelsen »en mand fra landet« er en bogstavelig oversættelse af en fast hebraisk vending, Am-ha'aretz, som Kafka i hvert fald kendte i sin jiddische udgave, Amhoretz: ${ }^{39} \gg$ Amhoretz er imidlertid øgenavnet for en ignorant. $\ll^{40}$ En Amhoretz er et generelt set udannet menneske, der dog som type særskilt opfattes i modsætning til de skriftkloge udi Toraen. Manden fra landet kan herudfra forstås som en ulærd lægmand, hvis hidtidige negligering af loven som den guddommelige vejviser har gjort, at han ikke besidder den tilstrækkelige religiøse indsigt til at kunne krydse dørtærsklen til det hellige rum.

Et tegn på mandens uvidenhed om loven kunne være det mislykkede bestikkelsesfors $\varnothing \mathrm{g}$. Manden prøver med sine pakkenelliker - et gyldigt betalingsmiddel i den profane verden - at skaffe sig adgang til en religiøs virkelighed. Det kan ses som en ironisk kommentar til hans uvidenhed om lovens karakter. Situationen kan minde om en hændelse i samtalen i domkirken mellem Josef K. og den gejstlige: »»Hvad er det, du holder i hånden? er det en bønnebog? «»Nej«, svarede K., »det er et album over byens seværdigheder ««. ${ }^{41} \varnothing \mathrm{je}-$ blikket efter kaster Josef K. med heftighed brochuren fra sig, som om han ubevidst aner sin fejltagelse ved at anvende en verdslig guide på et åndeligt gebet.

Tolkningen af manden fra landet som en uvidende person, der ikke kender sin bestemmelse på grund af sin adskillelse fra loven, har ligheder med Kafkas biografi. Han var opvokset i Prag, men tilhørte ikke det tjekkiske folk, han talte og skrev tysk, men var ikke tysker, han var jøde, men i et fremmed land, og hverken hebraisk eller jiddisch var hans modersmål.

Kafka forvandt aldrig denne fundamentale identitetskonflikt i relation til omverdenen. Det var en vedblivende sprogligt og nationalt betinget fremmed- 
hedsfølelse, som han i høj grad så som resultatet af den adskillelse fra jødedommen, der skabtes af hans baggrund som delvist assimileret vestjøde. En af de alvorligste bebrejdelser, Kafka rettede mod sin fader $\mathrm{i} \gg$ Brief an den Vater $\aleph^{42}$ var da også, at dennes vestjødiske religionsdyrkelse var for overfladisk til at kunne overleveres til sønnen som et brugbart verdensbillede. ${ }^{43}$

Ligesom Kafka var det, er manden fra landet også en fremmed, fordi han har forladt sin hjemstavn for at opsøge loven. ${ }^{44}$ Fortolkningen af mandens religiøse uvidenhed som årsagen til hans udelukkelse fra loven ligger denne forståelse tæt på de psykologiske og eksistentielle indfaldsvinkler, idet ansvaret for udelukkelsen placeres i hans utilstrækkelige viden, vilje eller evne.

Man kunne imidlertid med lige så stor ret foretage den stik modsatte fortolkning og vægte dørvogterens ansvar i stedet for mandens. Dørvogteren udstedelse af adgangsforbuddet sker omgående efter mandens ankomst, og på den baggrund forekommer det usandsynligt, at det sker efter en vurdering af mandens egnethed. Tværtimod forekommer forbuddet umiddelbart grundløst, og hele fortællingen kan læses som dørvogterens uforståelige leg med mandens længsel. Han foregiver, at manden har en fremtidig mulighed for at blive lukket ind: »»Det er muligt«, siger dørvogteren, »bare ikke nu«« (Fl). Han lader manden blive i troen ved at lave sine småforhør, men de »udeltagende spørgsmål«(Fl) indebærer ingen reel chance. Da han mærker mandens ønske om at se ind gennem den åbentstående dør til loven, »ler han« (Fl), og lokker manden til at overtræde forbuddet, men beretter samtidig ikke blot om sin egen mægtighed, men også om de andre dørvogtere inde i loven.

Hvis loven repræsenterer en guddommelig vilje, så får dørvogterens overlegne attitude og hans morskab over mandens anstrengelser denne lov til at fremtræde i et sadistisk lys, som kulminerer med novellens sidste ord: »Der var ingen andre end dig, der kunne få adgang her, thi denne indgang var kun bestemt for dig. Nu går jeg hen og lukker den« (Fl). Dørvogteren har tilsyneladende under hele det mangeårige spilfægteri været vidende om mandens bestemmelse, men tilbageholder denne information til det øjeblik, hvor manden endegyldigt har forpasset sin chance. Eftersom den døende mand ingen gavn har af dørvogterens afsluttende oplysning, virker ordene om hans bestemmelse kun som en sarkastisk kommentar til hans hjælpeløshed.

Derved fremstår loven ikke som Toraens opfyldelige bud, men mere som en uudgrundelig guddoms magtdemonstration over for det uvidende menneske. At manden trods ukendskabet til sin bestemmelse alligevel har opsøgt loven indikerer, at loven har nedlagt denne bestemmelse i manden uden selv at give ham adgang dertil. Med andre ord har loven måske kaldt manden til sig, kun for at afvise ham på sin dørtærskel, ligesom K. i Slottet tilkaldes som landmåler, kun for derefter at blive forment adgang til slottet. 
Denne tolkning af »Foran loven «, hvor manden fra landet er overladt til den guddommelige lovs nåde og forgodtbefindende, skaber associationer til en bestemt bog i Gl. Test.: »Det er det urgamle Job-spørgsmål ... Således også i fortællingen »Foran loven $« \ll{ }^{45}$ Der er to væsentlige lighedspunkter. For det første har Job under sine lidelsesfulde prøvelser og manden fra landet under sin livslange ventetid en fælles erfaring af, at Gud (loven) manifesterer sig som et tavst fravær. Deres bønner besvares ikke.

For det andet afføder begge fortællinger »Job-spørgsmålet om Guds redelighed. $\aleph^{46}$ Der er også to væsentlige forskelle. For det første taler Gud tilsidst til Job, hvorimod mandens vision af lyset fra loven er en tvivlsom åbenbaring grundet hans blindhed. For det andet fører Gud »sin bestemmelse med ... ham til ende $\ll^{47}$ på en helt anden og lykkeligere måde, end Job frygter og kan forudse - med den didaktiske pointe, at det uvidende og afmægtige menneske ikke er i stand til at bedømme den alvidende og omnipotente Guds retfærdighed. ${ }^{48}$ Hvorimod manden fra landets uforløste endeligt sætter et stort spørgsmålstegn ved redeligheden i lovens handlemåde.

Set fra en religiøs synsvinkel reducerer Kafka derfor kontakten mellem Gud og mennesket fra Jobs Bog til en uoverstigelig afgrund og undlader samtidig at give nogen forsonende afklaring af spørgsmålet om den guddommelige magts retfærdighedsbegreb. At manden fra landet udelukkes fra loven i »Foran loven«, at Josef K. dømmes uden at møde sin dommer eller få at vide hvorfor i Processen, og at landmåler K. aldrig tilstedes adgang til slottet i Slottet, har således fået en kritiker til at beskrive menneskets erfaring af det absolutte eller Gudsforholdet i Kafkas værker med formlen »Trancendens som terror. « ${ }^{49}$

En indikation af at »Foran loven« skulle omhandle et problematisk Gudsforhold kan fås ved inddragelse af en af Kafkas mulige inspirationskilder. En af forestillingerne om sjælevandringen til Guds trone efter døden i jødisk mysticisme har en nær strukturel lighed med lovens indretning i novellen. Sjælen skal på sin vej opad gennem »syv planetariske sfærer«, hvor der på hver etage står »»dørvogtere « posteret til højre og venstre for indgangen til den himmelske hal gennem hvilken sjælen må passere i sin opstigning. «50

I »Foran loven« skildres tilsyneladende ikke en sjælevandring post mortem, men dennes metaforiske struktur overføres i stedet på en afbildning af det levende menneskes vej til Gud. Det afgørende interessante ved Kafkas omformning af den jødiske sjælevandringsmyte er imidlertid, at de syv sfærer med endestation i de himmelske haller transformeres til en potentielt uendelig række af dørvogtere og sale: »fra sal til sal står der dørvogtere, den ene mægtigere end den anden. Allerede den tredje kan ikke engang jeg tåle synet af « $(\mathrm{Fl})$.

Uanset om loven skal repræsentere menneskets vej til Gud før eller efter døden, fremstilles den religiøse opstigning som en uafsluttelig rejse. Selv om manden fra landet måske med sin handlingslammelse medvirker til at iscene- 
sætte sin udelukkelse, og selv om han måske kunne have tiltvunget sig adgang til lovens nederste sale, er det således højst tvivlsomt, om han nogensinde var ankommet til lysets kilde, den sidste sal, hvis den overhovedet findes.

Formodningen om, at »Foran loven « skulle tematisere adskillelsen mellem den guddommelige lov og mennesket, kan understøttes af yderligere to mulige inspirationskilder for novellen. Den første stammer ligesom sjælevandringsmyten fra jødisk mysticisme, hvor »Toraen blev portrætteret som et væsen, der residerede inde bag syv forkamre. $\aleph^{51}$ Mystikerens vej gennem de 7 forkamre til den religiøse åbenbaring i mødet med Toraen skildres som belagt med farefulde forhindringer, hvorfor det er essentielt for udfaldet af hans quest, at han ikke lader sig afskrække af modstand, men forfølger sit mål med ufravigelig beslutsomhed. I »Foran loven« fremtræder manden fra landet med sit angstfyldte og paralyserede væsen, hvis afmægtige brokkeri efterhånden ender i en infantil regression, nærmest som en karrikatur af mysticismens quest-figur.

Den anden stammer fra den såkaldte Midrash-litteratur (tidlige fortolkninger af Toraen), hvor det berettes om Moses' prøvelser under hans opstigning til himlen for at modtage Toraen, hvor han overvandt en konfrontation med nogle engle, som fors $\varnothing$ gte at spærre ham vejen. ${ }^{52}$ I relation til Moses, jødedommens idealtypiske forbillede for opnåelsen af en kontakt med Gud og den guddommelige vilje i Toraen, kan »Foran loven« ses som en moderne antimyte: »Kafkas lignelse præsenterer en situation, som er den totale antitese til den grundlæggende opfattelse af Tora-studier. $\ll^{53}$

Manden fra landet inkarnerer ifølge denne opfattelse »den kraftesløse passivitet hos det moderne menneske«, som har mistet »sin levende forbindelse med loven - Toraen, « og også mistet »sin evne til at genskabe denne forbindelse. $«^{54}$ Toraen blev givet for at blive studeret, så mennesket kunne erfare Guds vilje og derved blive i stand til at opfylde sin guddommelige bestemmelse. Manden fra landet symboliserer måske det sekulariserede menneske, som har fjernet sig så meget fra loven, at det ikke mere kan finde tilbage til sin bestemmelse. Som argument herfor kunne man se mandens mislykkede fors $\emptyset \mathrm{g}$ på at få adgang som udvandede, virkningsløse reminiscenser af tidligere kultisk praksis: bestikkelsesfors $\emptyset$ get i stedet for offerritualet, studiet af dørvogteren i stedet for af loven, bønnerne til dørvogteren i stedet for bønnen til Gud.

Det kan således sandsynliggøres, at imaginationsmønstret og handlingsforløbet i Kafkas fortælling er modelleret over motiver fra jødedommens forestillingsverden, hvoraf dog ingenlunde følger, at den religiøse indfaldsvinkel kan betegnes som autoritativ eller uproblematisk. Tværtimod kan den religiøse forståelsesramme udsættes for en række indvendinger på primært to niveauer. For det første kan den religiøse synsvinkel foranledige flere og indbyrdes modstridende udlægninger af teksten. Er loven Toraen, en for mennesket uerkendbar guddommelig lov eller Gud selv? Er manden fra landet et hjælpeløst 
offer for en guddommelig lovs narrespil af sadistisk tilsnit eller selv ansvarlig for sin udelukkelse grundet sin åndelige uvidenhed? Skildrer novellen en epistemologisk bestemt og eviggyldig adskillelse mellem det menneskelige og guddommelige univers, eller inkarnerer manden som kontrastfigur til mystikerne og Moses det moderne menneskes rådvildhed i en sekulariseret verden? Er mandens søgen forgæves, eller er lysglimtet fra loven den højeste erkendelse et menneske kan opnå? Betyder lovens arkitektoniske uendelighedskarakter, at Gud har fjernet sig fra mennesket eller at mennesket har fjernet sig fra Gud eller måske, at Gud enten ikke findes eller ikke kan findes? For det andet - og langt mere grundlæggende - kan selve gyldigheden af den religiøse fortolkningsmodel betvivles. Nøjagtig som det var tilfældet med de tre foregående synsvinkler er også den religiøse synsvinkel en tolkningsmæssig konstruktion, der hviler på en tvivlsom oversættelse af tekstelementerne til en terminologisk forståelsesramme, som ikke har noget direkte anknytningspunkt i novellen.

Der står »loven«, ikke hverken Tora, Gud, jødedom, religion, troende, mystiker, himmel, åndelig, jordisk, sekularisering, Job eller Moses. ${ }^{55}$ At »Foran loven « muligvis betjener sig af motiver fra jødedommens forestillingsverden kan i forlængelse heraf omvendes til et argument for, at novellen ikke omhandler en religiøs tematik, fordi disse motiver netop er løftet ud af deres oprindelige religiøse univers, omarbejdede og indsat i en ny sammenhæng, hvor det religiøse element, hvis det findes, kun er tilstede i form af vage antydninger og mere eller mindre plausible intertekstuelle allusioner.

Som en foreløbig konklusion på de fire analytiske indfaldsvinkler kan det følgelig konstateres, at »Foran loven« tilsyneladende både inviterer til og afviser tolkningsfors $\varnothing \mathrm{g}$ - som lovens dør både er åben og spærret, som dørvogteren både udsteder adgangsforbud og lokker manden til at overtræde det.

I Processen afføder fortællingen af dørvogterhistorien en lang eksegetisk diskussion mellem Josef K. og præsten, som i sidste ende mere tilslører end oplyser tekstens betydning. Tolkningsproblemet synes altså centralt, hvorfor denne artikels sidste indgangsn øgle til tekstens dør skal være et fors $\emptyset \mathrm{g}$ på at unders $\varnothing \mathrm{ge}$, hvilke narrative mekanismer, der styrer læsningen af »Foran loven«. Hvorfor er det umuligt at fortolke novellen, og hvorfor er det umuligt at lade være?

\section{En tolkningens lov?}

Kafka-kritikken hæfter ofte genrebetegnelsen parabel på »Foran loven«, fordi præsten i Processen fortæller Josef K. historien som en lignelse om dennes relation til retten, men Kafka anvendte selv benævnelsen »der Legende. $\aleph^{56}$ 
En legende var oprindeligt en opbyggelig helgenhistorie, men den er senere blevet omdefineret som betegnelsen for en fantastisk fortælling, hvor det fiktive univers opstiller nogle værensbetingelser, som er væsensforskellige fra den reale virkeligheds rammer. Dette element kan i »Foran loven« konkret iagttages i materialiseringen af begrebet loven, som bliver til en bygning med indgangsport og sale. Ved omformningen af begrebet loven til en fysisk genstand rykkes fortællingen bort fra en tilstræbt realistisk virkelighedsgengivelse og ind i et mytisk eller eventyragtigt univers.

Legenden er da også beslægtet med ældre fortælleformer som myten og eventyret, der kendetegnes ved nogle relativt faste og skematiske narrative træk. »Foran loven« kunne således beskrives som en quest-myte, hvor protagonisten efterstræber en initiation ind i en højere åndelig eller erkendelsesmæssig virkelighed. ${ }^{57} \gg$ Foran loven « kunne ligeledes beskrives som et eventyr ved en sammenholdelse af fortællingens struktur med nogle af de funktioner, som Vladimir Propp fandt var karakteristiske for det russiske folkeeventyr. Det drejer sig især om funktionerne XI-XIV, hvor helten forlader hjemmet (XI), udsættes for en prøvelse, fx en udspørgen eller et forhør (XII), reagerer på prøvelsen, består (eller ikke består) testen (XIII), erhverver sig ved beståelse af testen en magisk hjælper, enten i form af et objekt, en viden eller evne, eller i form af en hjælperfigur (XIV). ${ }^{58}$

I »Foran loven « har manden fra landet forladt sit hjem, han møder en prøvelse (adgangsforbuddet) og en test (forhørsseancerne), som han forgæves forsøger at bestå (bestikkelsesforsøg og bønfaldelser) og anmoder tilsidst lopperne i dørvogterens pelskrave om hjælp. Dertil kommer, at dørvogterrækken repræsenterer en stribe prøvelser med stigende sværhedsgrad som potentielt er uendelig, men det er næppe tilfældigt, at den underste dørvogter ikke kan udholde synet af netop den tredje dørvogter. Prøvelsernes tredeling med en stigende sværhedsgrad er en typisk eventyrformular. Ved at benytte sig af disse genkendelige genrekonventioner inviterer »Foran loven « læseren til at forvente en traditionel eventyrstruktur med bestemte prøvelser, der skal bestås, hvorefter en belønning udløses. Dette narrative skema strukturerer delvis novellen, men undervejs undergår det nogle transformationer, som afføder forventningsbrud og frustration hos læseren.

Dørvogterrækken forlener prøvelserne med en uendelighedskarakter, som gør dem uløselige, forhørsseancernes »teilnahmslose Fragen « antyder, at de ikke udgør nogen reel test med en mulighed for beståelse, og lopperne i dørvogterens pelskrave fremtræder som en parodi på eventyrets hjælperfigurer. I »Foran loven « findes ingen tilfangetagen prinsesse og en drage, som helten kan dræbe, hvorefter han som belønning kan få pigen og det halve kongerige. I stedet findes en opgave, som protagonisten ikke kender, og derfor heller ikke 
ved, hvordan han skal løse, og derfor aldrig kommer til sin bestemmelse, som han heller ikke kender, før det er for sent. Denne uvidenhed har foranlediget Kafka-kritikeren Bert Nagel til at sammenligne manden med de mytiske helteskikkelser i Sofokles' antikke drama Kong Ødipus og Wolfram von Eschenbachs middelalderepos Parzival. ${ }^{59}$ Nagel koncentrerer sig om lighedspunkterne mellem fx det antikke verdensbillede og Kafkas værk: »tragisk Ikkeviden« udgør begge steder »den egentlige kerne i menneskets Sisyfos-eksistens. « ${ }^{60}$

Mere interessant end dette tematiske sammenfald er imidlertid forskellene på de mytiske heltefigurer og manden fra landet. Mens riddertumpen Parzival efter vel overståede prøvelser tilsidst opnår de tilstrækkelige kvalifikationer og den nødvendige viden for at få adgang til Gralsborgen og indtage sin prædestinerede position som konge, dør manden fra landet uden at have fået adgang til loven. Og mens Ødipus' selvblinding bliver et tegn på hans sluttelige indsigt (han bliver den blinde seer, ligesom Teiresias), så skaber mandens blindhed tvivl om gyldigheden af hans vision af lyset fra lovens dør.

Det afgørende ved disse ligheds- og forskelsrelationer for den fortællemæssige konstruktion $\mathrm{i} »$ Foran loven« er, at den opbygges af nogle grundlæggende - og fra myte, legende og eventyr genkendelige - narrative skemaer, som herefter omskabes eller dekonstrueres. I Kafkas legende berøves vi den slutning, som i Kong Ødipus eller i Parzival kan begrunde, oplyse, forklare og forsone os med hændelserne (bl.a. heltens prøvelser) i det hidtidige fortælleforløb.

Det narrative begær efter en forløsende slutning, som det eventyragtige plot iscenesætter hos læseren, indfris ikke. I stedet får fortællingen en slutning, som sætter et provokerende spørgsmålstegn ved meningsfuldheden i det fremstillede konfliktforhold. Slutningen nægter ikke blot læseren den konfliktløsning (mandens adgang til loven), som den narrative struktur skaber forventning om, men komplicerer konflikten yderligere, og forholder oven i købet læseren en forsonende forklaring på, hvorfor den ikke løses.

Denne anti-slutning afrunder ikke fortællingen, men giver grobund for en ny begyndelse, hvorved »Foran loven« antager en nærmest cirkulær form. Eftersom slutningen ikke ekspliciterer årsagen til mandens udelukkelse fra loven, men tværtom intensiverer problematiseringen af dette tema ved at udpege indgangen som bestemt for ham, tvinges læseren til at begynde forfra på fortællingen for at finde svar på det spørgsmål, som slutningen ikke besvarer, men stiller: Hvad er meningen?

I kraft af denne cirkulære gentagelsesstruktur kommer læsningen af »Foran loven« til at mime tekstens indholdsst $\varnothing$ rrelse. Som manden med sit ufravigelige adgangsønske overfor det vedblivende forbud tvinges til at gentage sine forsøg på at få adgang til den både åbne og blokerede lov, således tvinges læseren til at genlæse fortællingen for at finde en adgangsgivende kode til tekstens lov. Som manden foran loven, således læseren foran teksten. 
Forståelsesesprocessens vanskeligheder udspringer af tekstens (ligesom lovens) både åbne og lukkede form. Denne dobbelthed opstår i sammenstødet mellem indstiftelsen af de mytiske eller eventyragtige genrekonventioner og bruddet på dem. Først inviteres læseren til at fortolke teksten på nogle bestemte, narrativt genkendelige præmisser (som dørvogteren lokker manden fra landet til at træde ind i loven), hvorefter læserens fortolkningsfors $\varnothing \mathrm{g}$ strander (som manden ikke får adgang til loven), fordi teksten underminerer, opløser og bryder med de forventninger, som den selv har skabt.

Denne dobbelthed af invitation og afvisning, som bliver til en ny invitation og afvisning osv., producerer en frustrerende usikkerhed hos læseren, som ikke formindskes af den omstændighed, at fortællingens omdrejningspunkt (loven) aldrig defineres, aldrig får et indhold.

Hvor afgørende dette punkt er for fortolkningen kan skitseres ved en indsættelse af tekstelementer fra »Foran loven« i Greimas' på baggrund af Propp udarbejdede aktantmodel. Hvis manden fra landet tildeles rollen som subjekt og modtager, må dørvogteren optræde som modstander, lopperne som karikerede hjælpere og loven indtage pladsen som objektet for subjektets begær.

Det særlige ved Kafkas legende set i forhold til et eventyr, hvor objektets position typisk kan indtages af prinsessen, er, at objektet ikke kan identificeres. På trods af sin massive og materielle tilstedeværen forbliver loven en ukendt størrelse.

Lovens uidentificerbarhed leder tanken hen på Wolfgang Isers receptionsæstetiske begreb »Leerstellen«. I analytisk øjemed kan »Leerstellen« kortfattet defineres som de huller eller ubestemthedssteder i en fiktiv tekst, der både muliggør og fordrer læserens meddigtende deltagelse som forudsætning for fortællingens tilblivelse. ${ }^{61}$ Loven er ikke en tom plads $\mathrm{i} »$ Foran loven, « forstået som et udeladt eller fortiet element i fortællingen. Men den er det i den forstand, at teksten aldrig afslører, hvad loven er.

Lovens funktion som »Leerstelle « gør den således til en velegnet projektionsflade for læserens imaginationskraft, hvilket skulle være eksemplificeret i denne artikel med de fire tematiske indfaldsvinkler til teksten. Det skulle ligeledes være fremgået, at det afgørende problem for disse indfaldsvinkler opstår i det øjeblik, hvor de glemmer, at den tolkningsmæssigt nødvendige oversættelse af loven til et andet begreb er en konstruktion, dvs. en indholdsmæssig determinering af de åbne narrative strukturer. I kraft af denne forglemmelse risikerer de tematiske tolkningsfors $\emptyset \mathrm{g}$ at gøre »Foran loven« til et spejlbillede for deres egen tilværelsesforståelse.

I forlængelse heraf har et generelt problem for den kritiske beskæftigelse med Kafkas legende netop været forholdet til den høje grad af ubestemthed i teksten. I forsøget på at overkomme den forståelsesmæssige usikkerhed er kritikerne hyppigt forfaldet til ønsket om entydighed. 
Her skal kun gives et par eksempler. Én ofte anvendt løsningsmulighed har været at forlænge tolkningen ind i forfatterens biografi. Forklaringen på mandens udelukkelse fra loven kunne da være, at han (ligesom Kafka) er ungkarl, og derfor ikke har opfyldt det centrale Tora-bud om ægteskab og mangfoldiggørelse. ${ }^{62}$ Denne udlægning baseres på et »Leerstelle«, nemlig mandens ægteskabelige status, og overser, at det faktisk ikke kan eftervises i fortællingen, om manden har opfyldt »livets lov «.$^{63}$ Man kunne ligesåvel forestille sig, at manden, i lighed med K. i Slottet, har forladt sin familie for at opsøge loven.

Et andet »Leerstelle « $\mathrm{i} »$ Foran loven«, som ofte har foranlediget reduktionistiske udlægninger, er spørgsmålet om manden fra landets mulighed for at få adgang til loven. Fra en kombineret psykologisk og eksistentiel forståelse af manden fra landet og dørvogteren som to modsatrettede kræfter i mennesket, forekommer det indlysende, at manden blot skulle være gået ind, fordi »til loven kan kun den komme, som vover skridtet. « ${ }^{64}$ Fra en religiøs opfattelse af teksten som en illustration af den absolutte adskillelse mellem Gud og menneske kan det derimod beskrives som en fejlagtig »fordom at mene, at manden blot uden videre skulle være trådt ind. ${ }^{65}$

Begge fortolkninger bygger på en kohærent og tilsyneladende gangbar argumentationsgang, og begge er overbeviste om deres tolknings rigtighed: »Kafkas lignelse »Foran loven» synes os nu at være blevet gennemsigtig og forståelig « ${ }^{66}$ Problemet er imidlertid, at de to tydninger af teksten er uforenelige modsætninger, hvorved de underminerer hinandens troværdighed.

Problemet opstår, fordi de to tolkninger i deres iver efter at gøre sig til herrer over tekstens betydning forsøger at absolutere sig selv som autoritative og udtømmende forklaringsmodeller. Herved blotlægges en fortolkningsmæssig faldgrube, som litterære analyser altid må vakle på kanten af, men som måske er særlig påtrængende, ikke kun i relation til »Foran loven«, men også i den generelle litteraturkritiske omgang med Kafkas forfatterskab: »Mere end ved fortolkningen af andre forfattere synes fortolkeren af Kafkas tekster at afbilde sig selv i sine fortolkninger. $\ll^{67}$

Dette spejlbilledesyndrom i Kafka-kritikken, som denne artikel selvfølgelig ikke er nogen undtagelse fra (!), forekommer på baggrund af »Foran loven« ikke at være nogen tilfældighed. De usikkerhedsmomenter, som den narrative struktur skaber for forståelsesprocessen, og de projektionsfelter, der udgøres af et »Leerstelle« som loven, ikke blot inviterer læseren til at spejle sit verdensbillede i teksten, men fordrer med provokerende påtrængenhed en meddigtende fortolkning for overhovedet at gøre fortællingen til en meningsgivende konstruktion. At dette ikke kun er tilfældet $\mathrm{i}$ »Foran loven«, men måske har generel gyldighed for Kafkas værker, kan anskueligg øres ved, at de øverste niveauer i retten i Processen og slottet i Slottet indtager omtrent samme $»$ Leerstelle«-funktion i de to romaner som loven i legenden. 
Det potentielt farlige ved den tolkningsmæssigt nødvendige meddigtning er imidlertid, at kritikeren i ønsket om at give en restløs og autoritativ fremstilling af teksten kan overse, at selve forudsætningen for den tekstanalytiske konstruktion - nemlig tekstens ubestemthed - også er årsagen til, at enhver udlægning kun kan tildeles relativ gyldighed. Som loven måske udgør en uløselig gåde for manden fra landet, således udgør teksten for læseren en gåde, som ikke har nogen entydig løsning. Der findes en række løsninger, som alle hver for sig er både sande og falske. Sande, forsåvidt deres gyldighed analytisk kan begrundes, falske i det omfang de præsenterer sig selv som enerådende og udtømmende forklaringsmodeller, hvilket kunne være betydningen af præstens ord om dørvogterhistorien i Processen: »En rigtig opfattelse af en sag og misforståelse af den samme sag udelukker ikke hinanden totalt «. ${ }^{68}$

Adskillige kritikere har tildelt »Foran loven« rollen som en tematisk fortolkningsnøgle, ikke blot til romanen Processen, men til hele Kafkas forfatterskab. ${ }^{69}$ I forlængelse af den analytiske fremgangsmåde i denne artikel med de skiftende synsvinkler, som repræsenterer fire hovedstrømninger indenfor Kafka-kritikken, kan »Foran loven « måske fremhæves som en nøgletekst, der ikke kun angår det indholdsmæssige plan i forfatterskabet, men også kan danne udgangspunktet for en læsestrategi.

Beskæftigelsen med »Foran loven«, hvor enhver fortolkning viser sig kun at have relativ gyldighed, kan bevidstgøre læseren om, hvordan det både er muligt og umuligt at læse Kafka. Af legenden kan således udledes en tolkningens lov, som ikke stiller spørgsmålet: »Hvad er meningen? « Men i stedet som en konsekvens af opmærksomheden overfor tolkningsproblemet spørger: »Hvad kunne meningerne være?«

Denne erkendelse kan fungere som et korrektiv til tendenserne inden for Kafka-kritikken mod, at de forskellige teoretiske indfaldsvinkler vil absolutere sig selv som forklaringsmodeller, men det burde måske ikke være nødvendigt, fordi det står i en vis forstand allerede i Processen: »Skriften er uforanderlig, og meningerne er tit kun et udtryk for fortvivlelse over dette. $\ll^{70}$

»Foran loven handler $i$ hvert fald ikke om aspargessuppe«.

En ven.

\section{En slags konklusion}

Som artiklen har demonstreret, er det muligt at fremsætte mere uddybende og velbegrundede, men måske mindre prægnante og underholdende kommentarer til fortællingen end ovenstående udelukkende negative udsagn.Hvad der 
derimod ikke er muligt, er at give et definitivt svar på spørgsmålet, om »Foran loven« er en samfundskritisk allegori over bureaukratiske magtovergreb, en psykologisk analyse af to modsatrettede kræfter i mennesket og en mislykket individuationsproces, et eksistensfilosofisk lærestykke om det subjektive valg og handlingens nødvendighed, et ateistisk og eksistentialistisk nødråb ud i et tomt univers, en religiøs lignelse om adskillelsen mellem Gud og mennesket, en absurd tragikomedie à la Samuel Becketts En Attendant Godot, en eller flere paradoksfyldte kombinationer af disse muligheder. Eller noget helt andet.

Hver eneste læsemåde kan blotlægge en ny tolkningsmulighed, som imidlertid aldrig - i kraft af at den netop selv kun er en mulighed - kan gøre krav på nogen absolut autoritet. Af samme grund kan de forskellige synsvinkler på »Foran loven « $\mathrm{i}$ denne artikel hverken hver for sig eller tilsammen udgøre nogen blot tilnærmelsesvis endegyldig helhedsforståelse, der prætenderer at have udtømt tekstens muligheder for betydningsdannelse.

Der kan tænkes andre tolkningsmæssige udlægningsmåder af de tematiske synsvinkler (den samfundsmæssige, den psykologiske, den eksistentielle og den religiøse) end de muligheder, som denne artikels tekstanalyser har realiseret. Der kan ligeledes tænkes alternative synsvinkler, som slet ikke er med.

For eksempel kunne det, i en postmoderne og tegnbevidst tidsalder, muligvis være fristende at opfatte de tolkningsmæssige vanskeligheder ved legendens høje grad af ubestemthed som et argument for at se »Foran loven« som en illustration af dekonstruktivistiske tankegange - måske loven som et uholdbart transcendentalt signifié og dørvogterrækkens uendelighedskarakter som et udtryk for forskydningen eller udsættelsen af mening.

Også denne synsvinkel ville imidlertid kun indebære en omtrentlig og tvivlsom oversættelse af legendens tekstelementer til et terminologisk system, der højst kan besidde en relativ gyldighed som forklaringsmodel. Med »Foran loven « - og mange af sine andre værker - skabte Kafka et fiktivt univers, som både inviterer til og undviger tolkningsfors $\emptyset$ g. Således kan ethvert tolkningsfors $\varnothing \mathrm{g}$ i bedste fald kun gøre sig håb om at være både en meningsgivende tekstanalytisk konstruktion og et håbløst udfald mod tekstens tilslørede dør.

Som afslutning på den eksegetiske diskussion mellem præsten og Josef K. i Processen, hvor præsten gang på gang har tilbagevist Josef K.'s mere og mere fortvivlede forsøg på at fastlægge en entydig og endegyldig fortolkning af dørvogterhistorien, fremsættes flg. fortællerkommentar til Josef K.'s sidste tolkningsfors $\emptyset \mathrm{g}$ : »K. sagde det afsluttende, men det var ikke hans endelige dom. $\ll^{71}$

Dørvogterhistoriens narrative struktur gør det utænkeligt, at en sådan endelig dom nogensinde skulle kunne fældes over legenden, men det er samtidig årsagen til, at det fortfarende vil være både nødvendigt og interessant som læser at stille sig foran teksten $»$ Foran loven $\ll$. 


\section{Noter}

1. Der citeres fra den danske oversættelse af »Vor dem Gesetz«: »Foran loven« af Villy Sørensen in Franz Kafka: Dommen og andre fortcellinger, Kbh. 1984, p. 158159. Alle citater herfra markeres kun med forkortelsen (Fl) i brødteksten, da novellens korte længde overflødiggør sideangivelser. Med mindre andet angives er alle henvisninger til Kafkas $\emptyset$ vrige skrifter i flg. udgave: Franz Kafka: Gesammelte Werke (ed. Max Brod), Frankfurt am Main 1983. Med mindre andet angives er alle oversættelser til dansk fra fremmedsprogede værker mine egne.

2. Se Ulf Abraham: Der Verhörte Held, München 1985, p. 115.

3. Sådan er Josef K.'s skæbne i Processen hyppigt blevet udlagt. Den samfundsmæssige synsvinkel ligger i $\varnothing$ vrigt i forlængelse af to typiske udlægninger af Kafkas litteratur i hans fædreland under det kommunistiske styre. Magthaverne mente i slutningen af 1960'erne under den kortvarige opblødning af det totalitære samfundssystem og dets censurregler at kunne gøre Kafka salonfähig ved at forvandle ham fra »dekadent nihilist [Georg Lukács' fordømmende karakteristik, KN] til revolutionær kritiker af den kapitalistiske fremmedgørelse, « Ernst Pawel: Franz Kafka. Fornuftens mareridt, Kbh. 1992, p. 7. En udlægning som også venstreorienterede vestlige intellektuelle kunne tilslutte sig. (Efter Prager-foråret i 1968 blev Kafkas værker dog igen forbudt læsning i hans hjemland.)

Det politiske set omvendte gjaldt intellektuelle og systemmodstandere i Prag, som tenderede mod en »quasi-realistisk læsemåde«, der involverede en umiddelbar genkendelse af situationer fra den personlige livsverden, hvor det enkelte individ var blevet et magtesløst offer for både skrevne og især uskrevne regler (som man fx kan studere hos Milan Kundera i Tilvarelsens ulidelige lethed) i den totalitære, og delvist usynlige, kommunistiske magtstruktur, jvf. Jiri Stromsík: »»Kafkárny «-kafkaeske Situationen im totalitären Alltag, « in Hans Dieter Zimmermann, ed.: Nach erneuter Lektüre. Franz Kafkas »Der Prozeß«, Würzburg 1992, p. 272.

4. En pudsig indikation af den samfundsmæssige synsvinkel som en nærliggende forklaringsmodel for »Foran loven« er, at Kafka tilsyneladende har modelleret dørvogterens udseende efter nogle i samtidens virkelighed meget fremtrædende forbilleder, nemlig de barske, skæggede og pelsklædte dørvogtere foran adelspalæerne i Prag, residenserne for statsmagtens kransekagefigurer. Se Hartmut Binder: Kafka-Kommentar zu sämtlichen Erzählungen, München 1975, p. 185.

5. Hvis man ville drive læsningen helt ud på symboltolkningens overdrev, kunne man anvende den tvetydighed, der ligger i det ord, som Villy Sørensen har oversat med »lysskær«. »Glanz« kan ikke blot betyde »skin« eller »lys «, men er faktisk lydligt overensstemmende med dets mest bogstavelige oversættelse til dansk: »glans«.

6. Denne udlægning var på gale veje, idet ækvivaleringen af loven med den symbolske orden var en begrebsforvirrende omskrivning. Hos Lacan er loven »incestforbuddets adskillelse [af barnet, $\mathrm{KN}$ ] fra (identifikationen med) moderen, « Jørgen Dines Johansen: Psykoanalyse, litteratur, tekstteori, Kbh. 1977, bd. 1, p. 45.

7. Her vandrer jeg metodisk set i Erich Fromms fodspor. Han læste hele begivenhedsforløbet i Processen som en drømmelignende iscenesættelse af hovedpersonen Josef K.'s intrapsykiske konflikter, jvf..Erich Fromm: »Kafkas Roman »Der Prozeß, « in Gesamtausgabe bd. 9. Stuttgart 1981, p. 302.

8. Denne vertikale konstruktion af lovens indre rum ligner en trappe, et alment symbol på tiltagende vidensophobning og selverkendelse, jvf. Marianne Oesterreicher, ed.: Herder Lexicon Symbole, Breisgau 1982, p. 171-172. 
9. Den fraværende navngivning som vidnesbyrd om identitetsløshed genfindes i Slottet, hvor protagonisten er reduceret til bogstavet »K.«Og i Processen, hvor protagonisten kun i første linje har et fornavn (Josef), men herefter alene hedder »K.«

10. Mandens skæbne - ventende på tærsklen til tilblivelsen som en selvgyldig personlighed - minder påfaldende om Kafkas selvkarakteristik i et af hans mest kendte dagbogsnotater: »Mit liv er en tøven før fødslen, «Tagebücher, p. 411.

11. Manden foretager den projektivt udformede ansvarsforflygtigelse fra jeg til omverden, som Kafka andetsteds har udnævnt til at være en »gammel spøg«: »Vi holder verden og klager over, at den holder os« (»Die acht Oktavhefte«, p. 84).

12. En uforløst $\varnothing$ dipal relation med en tyrannisk faderfigur som en domsmagt, der fremkalder 'sønnens' undergang er en kendt struktur hos Kafka - både litterært (fx »Dommen « og »Forvandlingen «) og biografisk. Kafka opfattede 'sine skriverier' som et tildels mislykket frigørelsesfors $\varnothing$ g, jvf. »Brief an den Vater «, p. 148, Nov. 1919. Hertil også flg. dagbogsnotat fra 2. Dec. 1921, in Tagebücher, p. 403. Det er et næsten stereotypt billede af en ødipal konstellation, hvor den voksne søns personlighed er fastlåst i en tvungen gentagelse af barndommenss nederlagsoplevelser ligesom manden fra landet i forhold til dørvogteren $\mathrm{i} »$ Foran loven. «

13. »tanker på Freud selvfølgelig,« Tagebücher, p. 215, Den 23. sept. 1912.

14. Fx »Bende har ligeså mange bogstaver som Kafka og vokalen e gentager sig på de samme steder som vokalen a i Kafka, «Tagebücher, p. 217, Den 11. febr. 1913.

15. »Die acht Oktavhefte«, p. 90 og p. 79. Begge citater stammer fra 1918.

16. I modsætning fx til Camus' udlægning af Sisyfos-myten, som slutter med den paradoksale formulering: »Man må tænke sig Sisyfos som en lykkelig mand, « Albert Camus: Sisyfos-Myten. Oversat af Helga Vang Lauridsen, Kbh. 1979, p. 117.

17. Johannes Sløk: Eksistentialisme, Kbh. 1964, p. 86.

18. Lyset er et »symbol på immaterialitet, ånd, Gud men også liv eller lykke, « Oesterreicher op.cit., p. 101.

19. »Christendommen vil jo skænke den Enkelte en evig Salighed, et Gode der ikke uddeles i større Partier, men kun til Een og Een ad Gangen, « Søren Kierkegaard: Afsluttende uvidenskabelig Efterskrift. Første halvbind. Bind 9 i Samlede Varker, Kbh. 1991, p. 107.

20. »Uden Risico ingen Tro. Tro er netop Modsigelsen mellem Inderlighedens uendelige Lidenskab og den objektive Uvished,«ibid., p. 170.

21. Søren Kierkegaard: Afsluttende uvidenskabelig Efterskrift. Andet halvbind, Bind 10 i Samlede Varker, Kbh. 1991, p. 114.

22. Med Kierkegaards terminologi kunne manden fra landets manglende styrke karakteriseres som »sygdommen til døden, «jvf. Peter P. Rohde: Søren Kierkegaard. Et geni i en Købstad, Kbh. 1991, p. 33-34.

23. Camus, op.cit., p. 33-34.

24. Jean-Paul Sartre: Eksistentialisme er humanisme, Kbh. 1984, p. 64.

25. Hvis den ateistisk-eksistentielle fortolkning skulle fastholdes, kunne man lægge vægt på dørvogterens formulering efter forhørsseancerne: »og han ender altid med at sige, at han ikke kan lade ham komme ind endnu« (1. 24-26 - min kursivering). Denne tidsangivelse implicerer en reel fremtidig mulighed for, at dørvogteren kan tildele manden adgang. Denne udlægning ligger på linje med Josef K.'s umiddelbare reaktion på præstens fortælling af dørvogterhistorien i Processen

26. Dette har fået en eksistensfilosofisk kritiker til at identificere loven med »dødens fordring «, jvf. Gerhard Kurz: Traum-Schrecken. Kafkas Literarische Existenzanalyse, Stuttgart 1980, p. 167. Mandens tøven foran loven er udtryk for »livets 
rejse« (ibid.). Og novellens slutning betyder ikke, at mandens søgen var forgæves, men at hans livsrejse når sin bestemmelse. Skønt retorisk besnærende, forekommer denne udlægning mig reduktionistisk og fejlagtig. Det er imidlertid kendetegnende for tekstens flertydighed, at Kurz's fortolkning ikke helt kan afvises.

27. Sartre, op. cit., p. 50.

28. Jvf. Hochzeitsvorbereitungen auf dem Lande, p. 333.

29. »Fragmente aus Heften und losen Blättern«, p. 260.

30. Forestillingen om, at mandens passivitet gør ham skyldig, harmonerer med nogle af de fortolkninger af Processen, hvor manden fra landet opfattes som en parallelfigur til Josef K. Spørgsmålet om dennes eventuelle skyld for forløbet af sin proces har været et af de store diskussionsemner i Kafka-litteraturen; tendensen er til en koncensus om, at Josef K. bærer en stor del af skylden for sin egen undergang. Han er ikke et tilfældigt og sagesløst offer for et bureaukratisk overgreb, men dømmer derimod i vidt omfang sig selv. Jvf. således Max Brod: Über Franz Kafka, Frankfurt am Main 1989, p. 157 og Villy Sørensen: Kafkas Digtning, Kbh. 1968, p. 120). Disse fortolkninger af K. som skyldig svarer til Kafkas egen opfattelse: »Roßmann [protagonisten i romanen Amerika] og K., den skyldfrie og den skyldige, «Tagebücher, p. 351 - min kursivering. Citatet er fra 1915, hvorfor der med $» \mathrm{~K} . \ll$ menes denne i Processen, og ikke »K.«i den senere Slottet.

31. Selv om det hypotetisk antages, at manden kunne have passeret den første dørvogter, er det tvivlsomt, om han var nået forbi alle de andre dørvogtere. Hvis loven rummer et budskab bestemt for manden, kunne man ligesåvel forestille sig et forløb i lighed med fortællingen »Et kejserligt budskab«, hvor kejserens ord på dødslejet aldrig når deres adressat, jvf. »Eine Kaiserliche Botschaft«, p. 128-129.

32. Omfanget og arten af Kafkas religiøsitet er et omdiskuteret spørgsmål. I 1911 begyndte han et livslangt studie af det hebraiske sprog, det jødiske folks historie og jødedommens skrifter, jvf. Pawel, op. cit., p.225 ff. Han abonnerede resten af sit liv på det zionistiske ugetidsskrift »Selbstwehr«, hvor den oprindelige offentliggørelse af »Foran loven« fandt sted i 1915. At novellen fik sine første læsere i et medie, der var viet et jødisk trosfællesskab, kunne antyde, at forfatteren ikke var fremmed overfor inddragelsen af den religiøse dimension i tolkningen.

33. Edouard Nielsen og Bent Noack (red.): Gads Danske Bibelleksikon, bind 2, Kbh. 1981, p. 431.

34. Jvf. Wiebrecht Ries: Transzendenz als Terror. Eine religionsphilosophische Studie über Franz Kafka, Heidelberg 1977, p. 138.

35. Jvf. Bibelen (autoriseret oversættelse), Kbh. 1992, 2. Krøn. 23,19.

36. Jvf. Arthur A. Cohen \& Paul Mendes-Flohr (ed.): Contemporary Jewish Religious Thought, New York 1988, p. 67-69.

37. Ibid., p. 567.

38. Kafka beskrev i et brev til Felice Bauer, hvor central overholdelsen af lovens bud var for jødedommen: »at overholde budene er ikke noget udvendigt, men derimod kernen i den jødiske tro, «jvf. Pawel, op. cit., p. 325. I brevet siger Kafka samtidig, at han ikke selv ville være i stand til at overlevere den jødiske tro til børnene.

39. Jvf. Tagebücher, p. 130 (den 26. Nov. 1911).

40. Heinz Politzer: Parable and Paradox, New York 1966, p. 174.

41. Processen, op. cit., p. 190.

42. »Brief an den Vater«, p. 144-148.

43. Kafkas modtræk til faderens synagogereligion var østjødisk mysticisme. I »Rede über die Jiddische Sprache« (in Hochzeitsbereitungen auf dem Lande), ser han 
Jiddisch som legemliggørelsen af en oprindelig, åndelig og fællesjødisk identitet.

44. Dørvogterhistorien rummer i kimform hele plottet til romanen Slottet, hvor hovedpersonen K. - der både beskrives som »en fremmed« (Das Schloß, p. 50) og som »den mest uvidende« (ibid., p. 56) - forgæves forsøger at trænge frem til slottet.

45. Brod, op. cit., p. 155.

46. Ries, op. cit., p. 130.

47. Jobs Bog: 23,14.

48. Midt i Jobs ulykke fremsætter han et ønske, som bærer affinitet til tableauet i »Foran loven «: »Gid jeg vidste, hvordan jeg skal finde ham/og nå frem til hans bolig./ Så ville jeg fremlægge min sag for ham...« (Jobs Bog: 23,3-4).

49. Ries, op.cit., p. 93.

50. Gerschom S. Scholem i Major Trends in Jewish Mysticism. Citeret fra Politzer. Op.cit., p. 183.

51. Cohen \& Mendes-Flohr, op. cit., p. 654.

52. Associationen til Moses kan underbygges med henvisning til det stærke lys, der i begge tilfælde udgår fra »loven, «jfr. Anden Mosebog: 34,29-35.

53. Cohen \& Mendes-Flohr, op. cit., p. 655.

54. Ibid.

55. I kontrast til Brods skildring af Kafka som en religiøs skribent, kan fremhæves et dagbogscitat fra samme år som »Foran loven«: »Hvad har jeg til fælles med jøder? Jeg har knap nok noget til fælles med mig selv ...«Tagebücher, p. 255, 8.1.1914.

56. Tagebücher, p. 326, Den 13. Dec. 1914.

57. Kafkas romaner (Amerika, Processen og Slottet) er i overensstemmelse hermed blevet beskrevet som quest-fortællinger, der dog adskiller sig fra den traditionelle udformning, fordi »heltens problem ikke længere er »Kan jeg klare, hvad der kræves af mig? «men »Hvad kræves der af mig?«« jvf.Wystan Hugh Auden i Kafka's Quest. Citeret fra Bert Nagel: Kafka und die Weltlitteratur, München 1983, p. 15.

58. Jvf. Vladimir Propp: Morphology of the Folktale, London 1968, p. 39-50.

59. Nagel, op. cit., p. 149-153.

60. Ibid., p. 151.

61. Wolfgang Iser: Der Akt des Lesens, München 1990, p. 301.

62. Jvf. Hans Walther: Franz Kafka - Die Forderung der Transzendenz, Bonn 1977, p. 142-45.

63. Ibid., p. 145.

64. Martin Pfeifer: Franz Kafka, Amerika, Der Prozeß, Das Schloß, Hollfeld 1991, p.62.

65. Ries, op. cit., p. 139.

66. Pfeifer, op. cit., p. 65.

67. Hans Dieter Zimmermann: »Die Endlose Suche nach dem Sinn - Kafka und die Jiddische Moderne«, in Zimmermann (ed.), op. cit., p. 211.

68. Processen, op. cit., p. 198.

69. Fx Sokel, der anvender »Foran loven« som begrundelse for en primært psykologisk udlægning af Kafkas forfatterskab (jvf. Walter H. Sokel: Franz, Kafka - Tragik und Ironie, München 1964, p. 199), og Henel, der anvender samme tekst som en religiøs og eksistensfilosofisk forståelsesnøgle til Kafkas værker (jvf. Ingeborg Henel: »The Legend of the Doorkeeper«, in James Rolleston, ed.: Twentieth Century Interpretations of The Trial, Englewood Cliffs 1976, p. 54).

70. Processen, op. cit., p. 199.

71. Ibid., p. 201. 